\title{
Relationships between the Number and Power of Hungarian Household-Sized Photovoltaic Power Plants and Selected Indicators of the Settlements: A Case Study
}

\author{
Nóra Hegedúsné Baranyai ${ }^{1}$, Henrik Zsiborács ${ }^{1}{ }^{*}$, András Vincze ${ }^{1}$, Nóra Rodek ${ }^{2}$, Martina Makai ${ }^{2}$ and \\ Gábor Pintér 1 \\ 1 Renewable Energy Research Group, Soós Ernő Research and Development Center, Faculty of Engineering, \\ Nagykanizsa Campus, University of Pannonia, 8800 Nagykanizsa, Hungary; \\ baranyai.nora@uni-pen.hu (N.H.B.); vincze.andras@uni-pen.hu (A.V.); pinter.gabor@uni-pen.hu (G.P.) \\ 2 Faculty of Business and Economics, Nagykanizsa Campus, University of Pannonia, \\ 8800 Nagykanizsa, Hungary; rodek.nora@uni-pen.hu (N.R.); martina.makai@itm.gov.hu (M.M.) \\ * Correspondence: zsiboracs.henrik@uni-pen.hu
}

Citation: Baranyai, N.H.; Zsiborács, H.; Vincze, A.; Rodek, N.; Makai, M.; Pintér, G. Relationships between the Number and Power of Hungarian Household-Sized Photovoltaic Power Plants and Selected Indicators of the Settlements: A Case Study. Processes 2021, 9, 4. https://dx.doi.org/10.3390/ pr9010004

Received: 16 October 2020

Accepted: 18 December 2020

Published: 22 December 2020

Publisher's Note: MDPI stays neutral with regard to jurisdictional claims in published maps and institutional affiliations.

Copyright: () 2020 by the authors. Licensee MDPI, Basel, Switzerland. This article is an open access article distributed under the terms and conditions of the Creative Commons Attribution (CC BY) license (https: / / creativecommons.org/ licenses/by/4.0/).

\begin{abstract}
In the global transformation of energy systems, solar energy plays a prominent role, since the energy from our star is a limitless and clean resource, which is available practically almost everywhere. In spite of the immense advancements of photovoltaic systems, which utilize this source of energy, no in-depth research has been carried out regarding the present Hungarian status of the small-scale photovoltaic power plants, the most common type of solar power plant in Hungary. The novelty of this study is that it examines the number and power of these small-scale power plants at the settlement level within the service areas of the various distribution companies, by also considering the economic and infrastructural dimensions of the settlements. The paper seeks answers to the questions whether there are any significant relationships between the number and the power of power plants of this type and the indicators of the settlements, and if so, how strong they are. Besides pairwise correlations, the study also involved the analysis of the relationship between the ranking of the settlements based on the settlements' complex indicators that were created from the settlements' indicators and the ranking of the settlements according to the number and power of household-sized photovoltaic power plants per 1000 people. In the course of exploring the relationships, a regression model was also devised concerning the number of household-sized photovoltaic power plants and the settlement indicators.
\end{abstract}

Keywords: solar energy; photovoltaic system; small-scale power plant; economic; infrastructural settlement indicators; Hungary

\section{Introduction}

\subsection{Changes in the Spread of Photovoltaic Technology}

Boosting renewable energy production is seen by many countries as a viable way of mitigating climate change and transforming the energy systems [1]. This point can also be proven by the fact that by the end of 2017, more than 150 nations had set goals for developing the utilization of renewable energy [2]. It follows naturally from this that the global use of renewable energy (RE) is supposed to grow accordingly. It is predicted that by 2050, renewable energy sources (RES) will be responsible for the supply of approximately $60 \%$ of the world's final energy consumption, as a part of the worldwide struggle against the rise in global temperatures [1]. As for the newly installed global power capacities, investments in renewable energies will comprise more than $60 \%$ of these by 2040 [3,4]. All these developments are conducive to the truly important objective of the international community to keep the rise in global temperatures below $2{ }^{\circ} \mathrm{C}$ compared to preindustrial figures. This seems to be attainable if mankind aims for a rise of no more than $1.5^{\circ} \mathrm{C}$ [5]. 
One of the feasible ways of transforming the energy systems of the world in order to reach the climate targets described above by reducing the greenhouse effect is the increased utilization of variable renewable energy (VRE). Great technological advancements have resulted in the availability of many sustainable options, for example solar energy, whose role has become really significant by now. Among others, it is a remarkable achievement that many of the world's cities, whose populations keep growing constantly, have also developed their own solar energy programs. It is little wonder why solar energy is so often the preferred source of energy considering the fact that, besides being the most fundamental basis of most natural processes, it is also globally available, sustainable, clean, and plentiful [6-14]. The amount of the energy the Sun radiates towards the Earth surface annually is so great that it exceeds humankind's current need several thousand times [15-17]. Recently, the world has witnessed an amazing increase in photovoltaic (PV) technology; at the end of last year (2019), the world's total installed PV capacity was 627 GW. This clearly attests PV technology's paramount role in the evolution of a low-carbon economy, green growth, and achieving a higher proportion of renewables in global energy consumption. The important factors that have paved the way for this development during the last decade were manifold, including not only the introduction of the Feed-in-Tariff system but also the drop in capital expenditure needed for such investments thanks to successful innovation and advances in technology [18]. Depending on the geographical region, the average PV energy that can be produced in a given location in Europe ranges between 700 and $1900 \mathrm{kWh} / \mathrm{kW}$, as shown in the map below (Figure 1). In the case of Hungary, these figures reach 1050-1250 kWh/kW (Figure 1) [19].

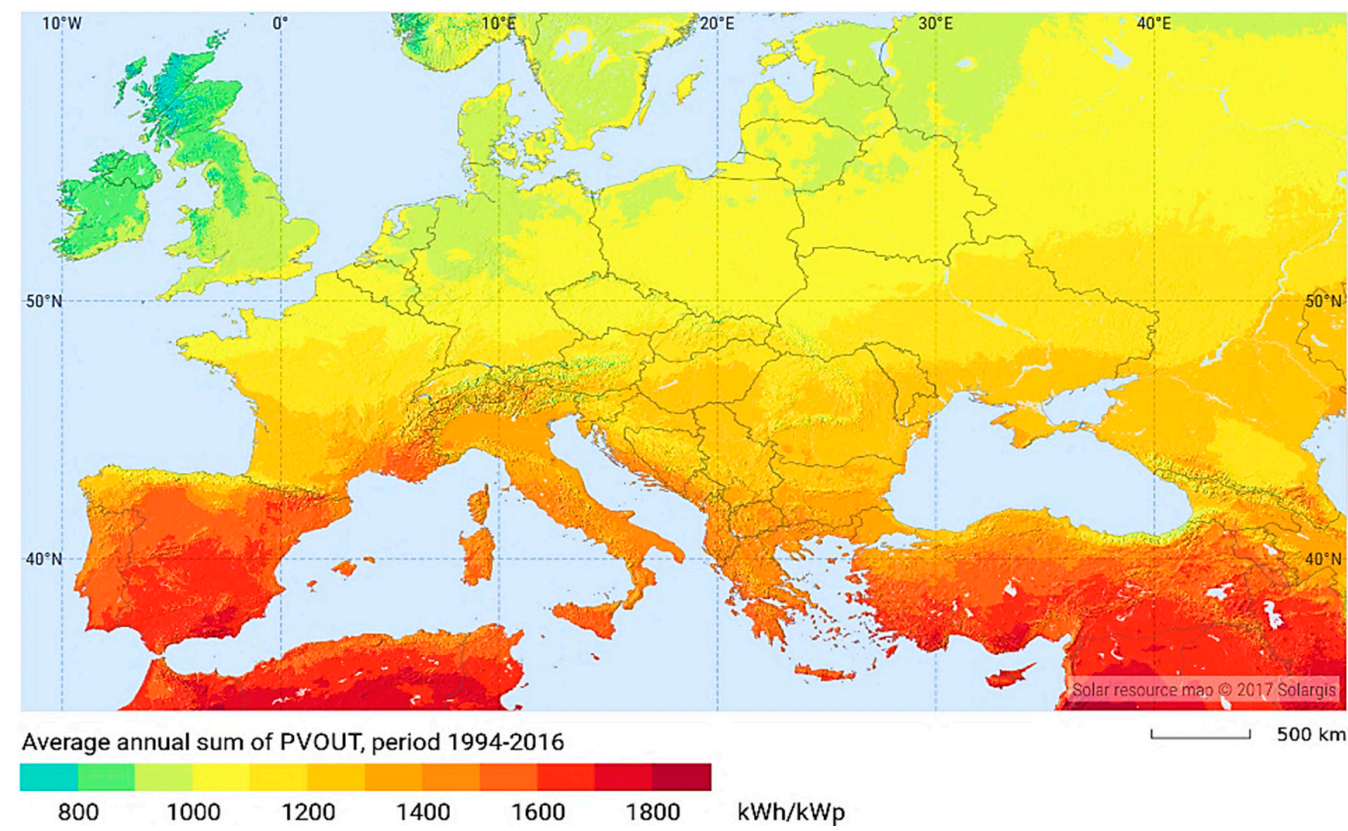

Figure 1. Europe's photovoltaic power potential [19].

This PV potential is also utilized by Hungary more and more, as witnessed by the past three years with a total installed capacity of about $0.31 \mathrm{GW}$ in 2017, $0.7 \mathrm{GW}$ in 2018, and $1.3 \mathrm{GW}$ at the close of the year 2019. This favorable development took place primarily thanks to changes in the regulations concerning PV [20,21]. PV systems are forecasted to continue to enjoy further growth in their spread. The Hungarian transmission system operator expects to have integrated 2.5-6.7 GW from PV by 2030, and 4.3-12 GW by 2040, based on three separate scenarios [22-24]. 


\subsection{The Hungarian System of Feed-in-Tariffs-Overview}

The world's nations show a remarkable diversity concerning the various ways in which they promote the use of green energy. To make things even more complicated, their schemes and regulations are often amended from year to year, which makes it hard to keep up with developments in the individual countries [25].

The last few years have brought several changes in PV regulations also in Hungary. On 1 January 2017, the Renewable Energy Support Scheme (METÁR) system, meant to promote electric energy generated from renewable sources, entered into force. Support under the METÁR scheme can be granted to electric power production that is related to a new investment and the realization of the investment has not been started at the time of application for the support. Power plants burning mixed fuel and/or waste can only receive support for the portion regarded as a renewable source of energy (proportional to combustion heat). A household-sized power plant (HMKE) system may not receive this support. In the METÁR scheme, support for new investments can only be applied for in the form of a green premium-type entitlement, which is granted in a tendering process. In the premium-type system, producers sell the electric power themselves, and the subsidy is paid above the market reference price. In this system, producers have to bear the costs of deviating from the 15-min schedules. The calls for tenders are decided on by the minister responsible for energy policy and they are managed by the Hungarian Energy and Public Utility Regulatory Authority (MEKH). The first call was announced on 2 September 2019, and the majority of the applications are related to PV technology [26].

One of the Hungarian tools of promoting electric power generation from renewable sources and/or waste is the Hungarian system of Supporting Green Energy from Renewable Energy Sources (KÁT) system, in which the electricity can be sold at a price that is higher than the market price and is determined by law. The subsidized prices are different for electric power from renewable sources and waste. In addition, they also differ according to size, the date of receiving entitlement, the zone time, and partly technology. The fact that the subsidized amount and the time period of eligibility within the framework of the KÁT system is set ensures that a producer can only receive support until the payback of their investment at the most. If the power plant is given any other subsidies, the period of eligibility is shortened proportionately. Because of changes in the legal regulations, no entitlement to KÁT support is granted any more to applications submitted after 31 December 2016 [26].

The smallest power plants are the so-called HMKEs, household-sized power plants, whose connection capacity does not exceed $50 \mathrm{kVA}$ at a connection point. By the installation of household-sized power plants, it becomes possible for consumers (e.g., private people, institutions, or businesses) to reduce the amount of power purchased from the public utility grid. In the case of HMKEs, accounts are settled based on the balance of the amounts of power purchased from the public utility grid and fed into the grid with the help of a special meter (sell-buy measuring device). The HMKE scheme does not require producers to provide 15-min power generation forecasts. It is only the consumption that exceeds the quantity of the power produced that needs to be paid for by the operator/owner of the PV system. Conversely, if the household-sized power plant generates more power than the electricity consumed, the service provider needs to pay the customer [26]. It is an interesting fact that in the fourth quarter of 2019 (Q4), according to the official data provision, a total of 4644 new HMKEs were connected to the grid with a total installed power of $36.58 \mathrm{MW}$. The overwhelming majority (99.5\%) of the installed HMKEs were PV systems. It is worth noting here that in that particular quarter (Q4 of 2019), one hydropower, five wind power, and one diesel HMKEs were joined to the network. In that quarter, the average installed power of the new PV HMKEs was $7.88 \mathrm{~kW}$. These figures indicate that HMKE systems are becoming increasingly important for private people, institutions, and businesses (Figure 2) [27]. 


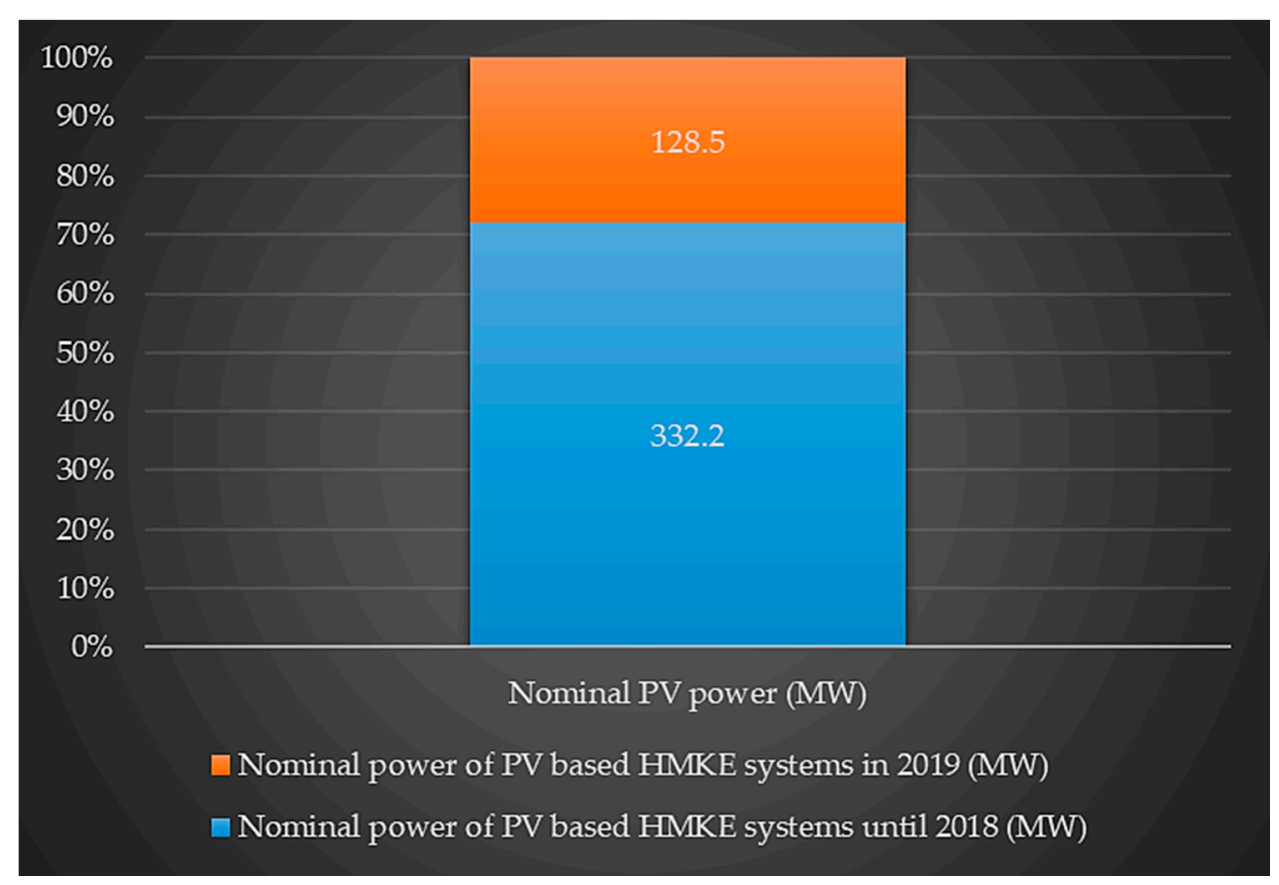

Figure 2. The nominal power of the PV HMKE systems in Hungary [27].

\subsection{Introduction to the Methodology of Regional Development Indicators in Hungary}

The investigations herein sought to confirm the hypothesis that the indicators of the settlements affected the spread of HMKEs. For this purpose, a database containing the settlements' indicators had to be compiled first. The examination of the development of regions looks back on a long history in both the international and the Hungarian contexts. In Hungary, there were initiatives to explore the possibilities and methods of measuring the level of development in the various regions already from the middle of the 1980s (in 1985 in the National Planning Bureau, in 1988-1995 in the Ministry of Environmental Protection and Regional Development). The first law (Decision of the Hungarian Parliament No 84/1993. (XI. 11.) [28]) was passed in 1993, and it meant the beginning of the methodological definition of the development measurements and underdevelopment classification of the regions, a process that is still ongoing.

Although the applied indicators have changed over time, the methodology of the calculations has showed relative constancy. At present, two government decrees are in force concerning regional development: Government Decree No. 290/2014. (XI. 26.) on the classification of beneficiary districts [29] and Government Decree No. 105/2015. (IV. 23.) [30] on the classification of beneficiary settlements and the conditions of classification. Several authors (KOVÁCS-BODNÁR 2017 [31], VALKÓ ET AL. 2017 [32]) point out that the more criteria are available about a region's economy and infrastructure, the more reliably its level of development can be assessed, and this, of course, requires reliable, controlled, and precise collection of data and their regular revision. It must not be forgotten either that the publication of regional data takes longer, and this time lag makes the formulation of conclusions more difficult.

This study is unique in the sense that in Hungary, no research has been done before to analyze the relationships between the spread of HMKEs and the indicators of settlements. However, at both the national economic and local levels, the design of well-founded energy strategies necessitates not only the analysis of factual data but also the exploration of the reasons behind them, which in turn is impossible without suitable databases.

For this research project, the indicators of the settlements were made available by the Central Statistical Office (KSH) [33] and the National Regional Development and Spatial Planning Information System (TEIR [34]), while the HMKE databases were provided by the electricity suppliers ELMÚ-ÉMÁSZ Energiaszolgáltató Zrt. (ELMÚ-ÉMÁSZ), E.on 
Hungária Zrt. (EON), and NKM Energy Zrt. (NKM). The analyses were carried out with regional analysis tools and mathematical-statistical methods for the year 2019, and the following were the hypotheses to be tested:

- $\quad$ Every particular settlement indicator is suitable for identifying relationships concerning the number and power of photovoltaic HMKEs.

- The ranking of the settlements based on the complex indicators derived from the settlement indicators shows a correlation with the ranking of the settlements according to the number and power of photovoltaic HMKEs/1000 people in Hungary.

- $\quad$ A regression model that can be used to determine the quantity of photovoltaic HMKEs in the settlements can be created.

\section{Materials and Methods}

\subsection{Methods}

If both cause(s) and effect(s) are quantitative criteria, we can speak of a correlation. Correlation calculation shows how one or more independent variables influence a dependent variable, and how strong their relationship is [35]. In the case of metric variables, Pearson correlation (parametric), while in the case of ordinal variables, Spearman (nonparametric) correlation can be applied. When examining the relationship of quantitative indicators, it is worth creating a so-called scatter plot before the identification of the indices. On the basis of empirical data, one can make assumptions about the strength and direction of the relationship from the pattern of the points. Results that are more exact can be obtained by determining the value of the Pearson correlation coefficient (r) in the case of linear relationships, and in the case of nonlinear relationships that of the correlation index (I). The Pearson correlation coefficient ranges from -1 to +1 . The closer the absolute value of $|\mathrm{r}|$ is to 1 , the stronger the correlation is, while an $|\mathrm{r}|$ equal to 1 one means a total linear correlation and 0 [36] no linear correlation. If the value is between 0 and 0.2 , the relationship is weak; if it is between 0.2 and 0.7 , it is moderately close; and over 0.7, it is considered strong. If $|\mathrm{r}|$ is a positive number, it signals a positive correlation; in the opposite case, it means a negative one. One can speak about a correlation only in the case of a significant result $(p<0.05)$. The Pearson correlation coefficient squared is the coefficient of determination, which gives information on what percent of the variance of the dependent variable can be explained by the independent variable [37].

The partial correlation coefficient differs from the coefficient of pairs in that in its calculation, the other variables are not disregarded but their effects are removed. The partial correlation coefficient thusly obtained shows how close the relationship is between a selected independent variable and the dependent variable if the effect of the other independent variables is removed from both the examined factor variables and the result variables. In the case of a positive correlation, the partial correlation coefficient is positive, while in the case of a negative one, it is negative, and its absolute value ranges from 0 to 1. The Pearson correlation coefficient always has to be compared to the partial correlation coefficient. No difference between the two correlation coefficients means that the controlled variable has no effect, but if the partial correlation coefficient equals 0 , there is a seeming relationship between the controlled and the original variables. Between two variables ( $i$ variable, $j$ variable), the relationship is examined by controlling a third variable ( $\mathrm{k}$ variable). The square of the partial correlation coefficient is called the partial coefficient of determination. The partial coefficient of determination gives information about what proportion of the part of the variance of the $Y$-dependent variable that cannot be explained by $X_{1}, X_{2}, \ldots, X_{p}$ variables can be accounted for by the $X_{j}$ explanatory variable [38].

The complex development index (CDI) indicates what difference in the level of development is detectable between settlements considering several indicators together. It poses, however, a problem that the indicators measuring the social, economic, and infrastructural underdevelopment/development of settlements have different units of measurement. A solution can be the transformation of the basic indicators onto a scale of identical range 
with a normalizing procedure according to the following formula (Government Decree 290/2014. (XI.26.) [29], Government Decree 105/2015. (IV. 23.) [30]:

$$
f a_{i, j \text { norm }}=\frac{f a_{i, j}-\min \left(f a_{i, j}\right)}{\max \left(f a_{i, j}\right)-\min \left(f a_{i, j}\right)} \times 100,
$$

where $f a_{i j}$ : normalized basic indicator, $\min \left(f a_{i j}\right)$ : the lowest value of the basic indicator, $\max \left(f a_{i j}\right)$ : the highest value of the basic indicator.

The average of the normalized indicators constitutes the complex indicator, based on which the settlements are ranked. Number 1 in the ranking is awarded to the settlement with the highest complex indicator. The settlements in this study were also ranked according to their HMKE indicators. Here, the number 1 also represents the settlement with the highest value. After this, the relationships were explored by rank correlation.

As the first step of the rank correlation calculation, the observed values of the variables are ranked and each item is given a number according to its rank from 1 to $n$, where $n$ is the number of units observed. What is examined here is to what extent the rankings of the variables match for the same units observed. For the characterization of the ordinal variables, Spearman's rank correlation coefficient $(\rho)$ can be used. Its value ranges between -1 and 1 , and if it is 0 , there is no relationship between the criteria. If the value is near 1 , the two rankings can be regarded as identical, while a value close to -1 indicates in inverse order [38].

The stochastic relationship between quantitative criteria is described by regression calculation in the form of a function. By using multivariate regression analysis, the effect of several criteria on the outcome variable can be examined. Depending on the type of the function, the relationship is either linear or nonlinear.

If the relationship between the outcome variable and the explanatory variables is linear, it can be described by the following formula (see Equation (2)):

$$
Y=\beta_{0}+x_{1} \beta_{1}+\ldots x_{n} \beta_{n}
$$

where $x_{1}$ to $x_{n}$ : independent variables, $Y$ : dependent variable, $\beta_{1}$ : the regression coefficient of variable $x_{1}, \beta_{n}$ : the regression coefficient of variable $x_{n}$.

By creating an optimal model, the goal of this research was to include in the function variables that substantially affect the dependent variable. This was achieved by improving the model significantly by including further variables, one at a time. A solution for this is provided by step-by-step regression techniques, which have three basic types [39]: stepwise regression, forward selection, and backward elimination. Each of these methods requires the examination of the potential variables separately and deciding whether the specific variable is needed in the model to be built, one by one. To decide whether the inclusion of a variable in the model causes a significant betterment compared to the state one step earlier, an F-test is applied. Further, the significance of the coefficient of the variable to be included is verified by a $t$-test.

In the forward selection process, the possible explanatory variables are examined one by one, and then it is decided if they are to be included. The procedure of backward selection is the exact opposite. All potential independent variables are included in the model in the initial stage of the study, and then the variables with the least effect on the dependent variable are eliminated in the successive iterative steps. The stepwise method is a combination of the first two. A new variable is included in each iterative step to improve the model significantly, and then it is decided whether one of the variables already included can be omitted without any statistically measurable deterioration in the quality of the model [37]. In the course of the investigations herein, the stepwise method was used.

\subsection{Material}

From the perspective of regional development, the beneficiary regions are determined according to government decrees. One of these, Government Decree 290/2014. (XI.26.) [29], 
which entered into force on 1 January 2015, regulates the beneficiary districts. In the classification of the districts according to their regional development, the decree takes the complex indicator that is created from social, demographic, housing, living condition, local economic, employment, infrastructural, and environmental indicators into account. The beneficiary districts, the districts to be developed, and the districts to be developed by complex programs are determined based on the complex indicators. On the other hand, the classification of the beneficiary settlements and the conditions of the classification are governed by Government Decree 105/2015. (IV. 23.), which came into force on 1 January 2017 [30]. This study was based on these two government decrees, whose annexes contain the formulas with which the complex indicator was calculated. Related to the economic dimension, the following settlement indicators were taken into account: number of enterprises per 1000 population, the budgetary revenue and expenditure of the municipalities per 1000 population, the number of operating commercial accommodation units per 1000 population, and the number of businesses in the hospitality industry per 1000 population. The two indicators associated with tourism were included in our research because our previous investigations had shown that the spread of HMKEs had been more intensive in regions affected more by tourism [40]. Out of the infrastructural indicators, the settlement-level data of the electricity sector (residential electricity consumers per 1000 population, electricity consumers per 1000 population, the length of the low-voltage electricity distribution network per 1000 population) were also analyzed. The indicators of the settlements were obtained from the Regional Statistics of the Hungarian Central Statistical Office (KSH) [33] and the database of the National Regional Development and Spatial Planning Information System (TeIR) [34]. For the purpose of the investigation, the eight indicators referring to the year 2018 (due to the time lag of the regional data, those of 2018 were the latest) were taken into account from the groups of the economic and infrastructural indicators (Table 1).

Table 1. Settlement indicators used in the development examinations.

\begin{tabular}{lc}
\hline \multicolumn{1}{c}{ Indicators } & $\begin{array}{c}\text { Symbol as Explanatory Variable } \\
\text { in the Model }\end{array}$ \\
\hline number of registered enterprises per 1000 population & $x_{1}$ \\
\hline $\begin{array}{l}\text { total revenue of the municipalities per 1000 population } \\
\text { (HUF 1000) }\end{array}$ & $x_{2}$ \\
\hline $\begin{array}{l}\text { total budgetary expenditure of the municipalities per } \\
\text { 1000 population (HUF 1000) }\end{array}$ & $x_{3}$ \\
\hline residential electricity consumers per 1000 population & $x_{4}$ \\
\hline $\begin{array}{l}\text { electricity consumers per 1000 population } \\
\text { length of the low-voltage electricity distribution } \\
\text { network per 1000 population (km) }\end{array}$ & $x_{5}$ \\
\hline $\begin{array}{l}\text { number of operating commercial accommodation } \\
\text { units per 1000 population }\end{array}$ & $x_{6}$ \\
\hline $\begin{array}{l}\text { number of businesses in the hospitality industry per } \\
1000 \text { population }\end{array}$ & $x_{7}$ \\
\hline
\end{tabular}

The photovoltaic HMKE database was compiled on the basis of the 2019 data of three electric companies (ELMÚ-ÉMÁSZ, EON, NKM). In 2019, the regions of the electric companies were modified, and the database used in this research corresponds to the new regional allocation, shown in Figure 3. Experience has shown that, unless some significant economic or social crisis occurs, the regional indicators do not demonstrate any considerable change from one year to another. Between 2018 and 2019, no such event took place, which allowed the use of the latest (2018) settlement indicators for these investigations and their comparison to the latest (2019) HMKE data. 


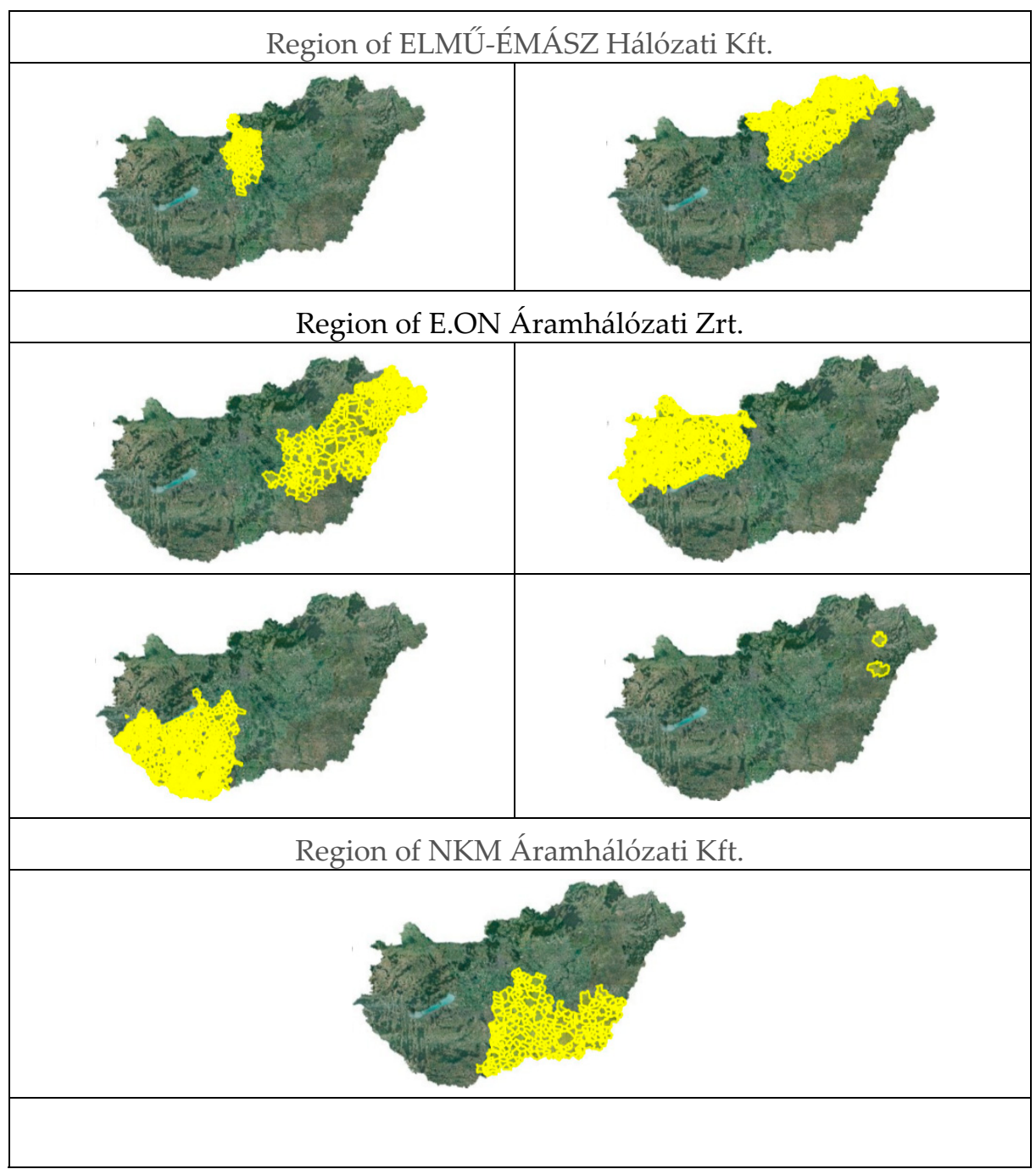

Figure 3. The regions of the Hungarian electric companies based on [41].

The electric companies provided us with data of different levels of detail, on the basis of which the examinations could be divided into three parts:

1. ELMÜ-ÉMÁSZ, EON (2417 settlements):

- Total HMKE power per 1000 population (kW);

- Residential HMKE power per 1000 population $(\mathrm{kW})$;

- Business HMKE power per 1000 population (kW);

- Total HMKEs per 1000 population (pcs);

- Residential HMKEs per 1000 population (pcs); and

- Business HMKEs per 1000 population (pcs).

2. ELMÛ́-ÉMÁSZ, EON, NKM (2631 settlements):

- Total HMKEs per 1000 population (pcs).

3. EON (1763 settlements):

- Total HMKE power per 1000 population (kW);

- Residential HMKE power per 1000 population $(\mathrm{kW})$;

- Public HMKE power per 1000 population $(\mathrm{kW})$;

- Business HMKE power per 1000 population $(\mathrm{kW})$;

- Total HMKEs per 1000 population (pcs);

- Residential HMKEs per 1000 population (pcs);

- Public HMKEs per 1000 population (pcs); and 
- Business HMKEs per 1000 population (pcs).

\section{Results and Discussions of the Correlation Analysis between the Number and Power of HMKEs and the Settlements' Level of Development}

This research primarily sought to find answers to the questions whether the number and power of the HMKEs in a given settlement correlated with the settlement's economic and infrastructural dimensions in Hungary, and if yes, to what extent.

The investigations first focused on the settlements that had HMKEs and where electricity was supplied by ELMÚ-ÉMÁSZ, EON, or NKM. Apart from the identification of the individual effects of the settlement indicators from the database containing the regions of all three electric companies and the demonstration of the relationships between the settlements' ranking according to these and the ranking of the settlements based on the quantity of HMKEs, it was a main objective of this research to create a regression model that shows the relationship between the settlement indicators (Table 1) and the quantity of total HMKEs per 1000 population at a national level. The resulting linear regression function can be seen here below (see Equation (3)):

$$
Y=\beta_{0}+\beta_{5} x_{5}+\beta_{1} x_{1}+\beta_{3} x_{3}=-2.534+0.01 x_{5}+0.013 x_{1}+0.000006 x_{3}
$$

where $x_{5}$ : the number of electricity consumers per 1000 population, pcs; $x_{1}$ : the number of registered economic organizations per 1000 population; $x_{3}$ : the total budgetary expenditure of municipalities per 1000 population. It was established that both the regression model and the parameters were significant $(p=0.000)$; furthermore, based on the value of are $\mathrm{R}$ (0.554), there was a moderately strong correlation between the explanatory variables of the model and the number of HMKEs per 1000 population, and the five indicators explained the differentiation of the quantity of HMKEs at the settlements' level to an extent of $30.7 \%$.

It was established that, concerning the settlements in the examined period, there was a positive weak moderate correlation between the following of the settlements' indicators: registered businesses per 1000 population, total budgetary expenditure of the municipalities per 1000 population, number of operating commercial accommodation units per 1000 population, number of businesses in the hospitality industry per 1000 population, and the number of total HMKEs per 1000 population. A somewhat stronger but still moderate correlation could be detected between the number of residential electricity consumers per 1000 population, the number of electricity consumers per 1000 population, and the quantity of total HMKEs per 1000 population (Table 2). The partial correlation coefficients showed that, although in most of the cases the controlled variables had some effect on the strength of the relationship, this effect did not significantly modify the correlation. 


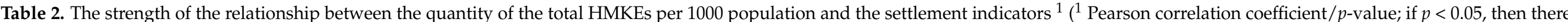

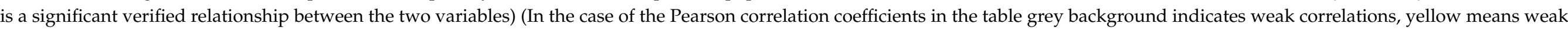

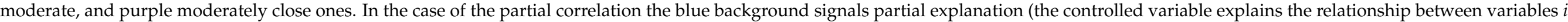
and $j$ only partially), while the black one shows irrelevant comparison.

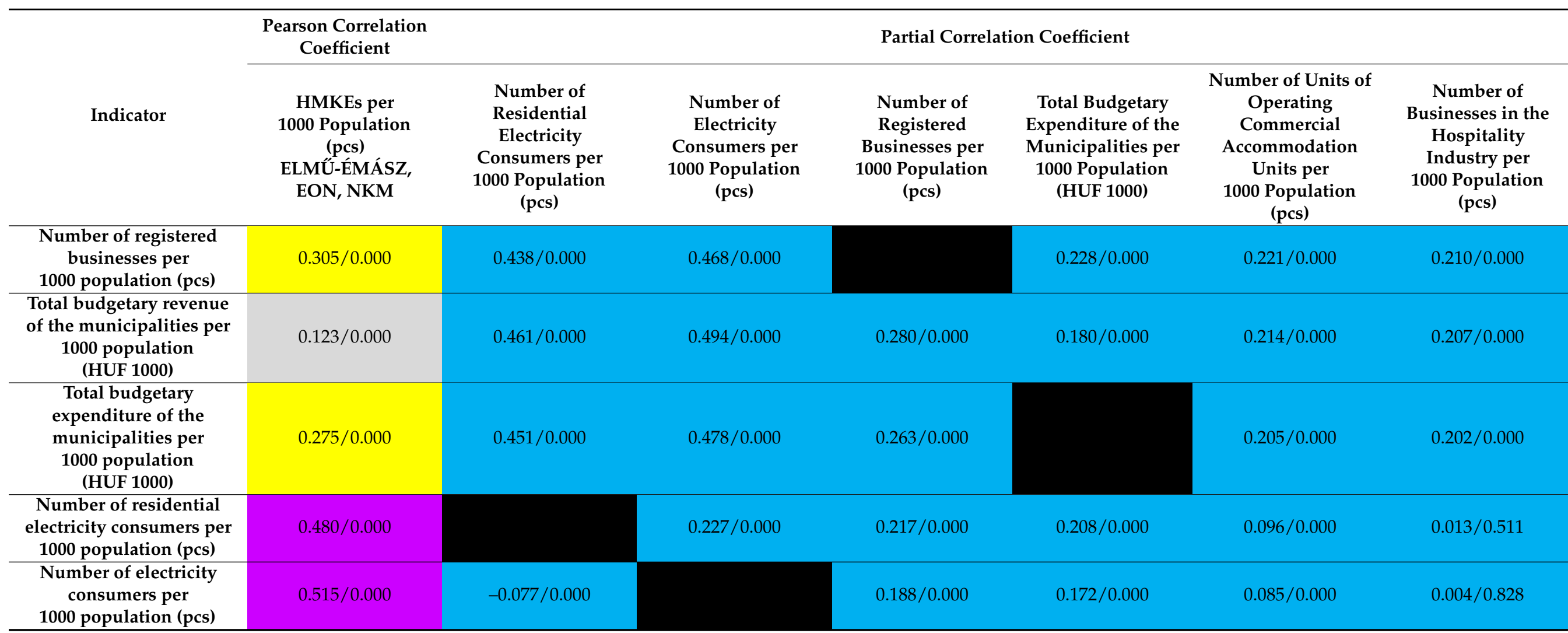


Table 2. Cont.

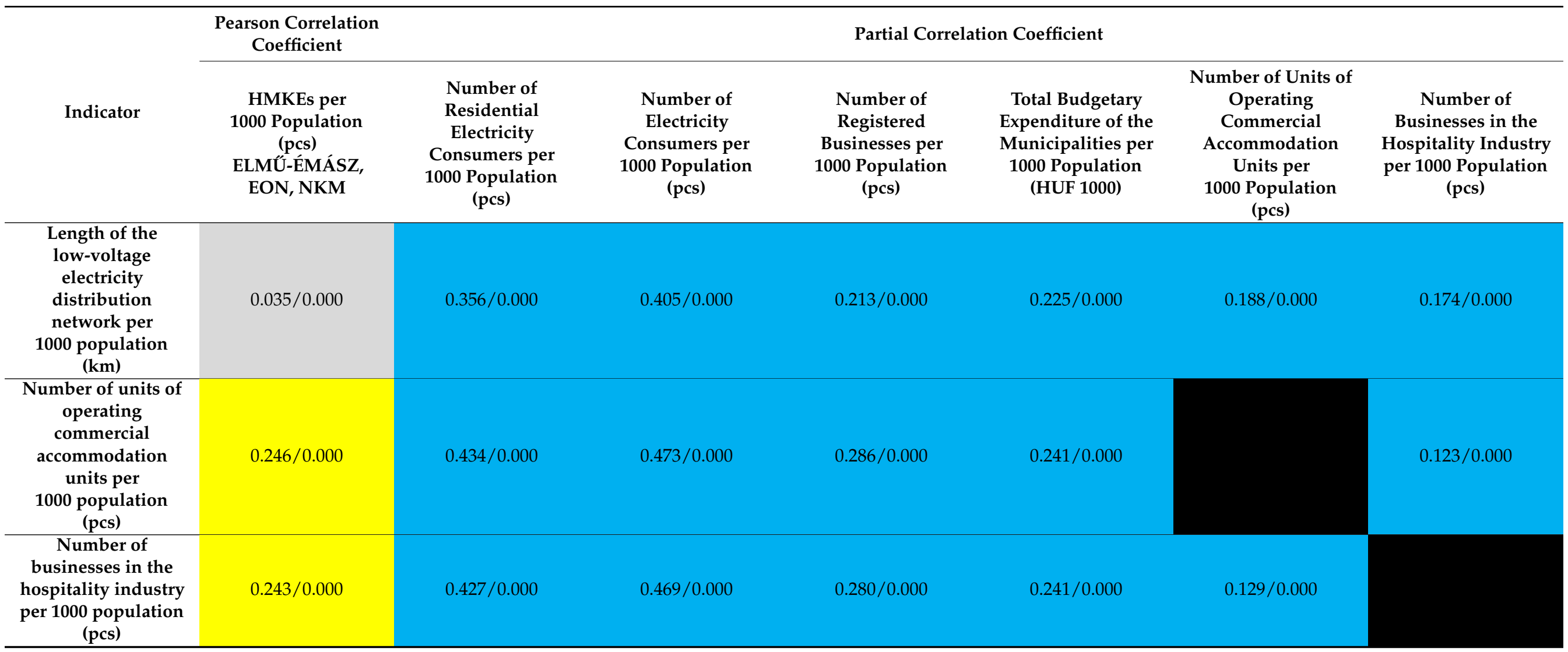


The ranking of the settlements based on the settlements' complex indicators and the ranking according to the number of HMKEs per 1000 population indicated a positive weak moderate correlation $(\rho=0.226, p=0.000)$.

Next, those 2417 settlements were analyzed where ELMÚ-ÉMÁSZ and EON are the providers of electricity. Regarding these settlements, it was possible to examine the power of the HMKEs apart from their numbers with regard to both the residential and the business consumers.

It was established that concerning the settlements in the examined period, there was a positive weak moderate correlation between the following of the settlements' indicators: the number of registered businesses per 1000 population, the total budgetary revenue of the municipalities per 1000 population, the total budgetary expenditure of the municipalities per 1000 population, the number of businesses in the hospitality industry per 1000 population, and the power and the number of total HMKEs per 1000 population. The relationship between the number of total HMKEs per 1000 population and the number of units of operating commercial accommodation units per 1000 population was also a weak moderate positive one. Between the number of residential electricity consumers per 1000 population, the number of electricity consumers per 1000 population, the length of the low-voltage electricity distribution network per 1000 population, and the total power of HMKEs per 1000 population there was also a weak moderate correlation. Between the number of residential electricity consumers per 1000 population, the number of electricity consumers per 1000 population, the length of the low-voltage electricity distribution network per 1000 population, and the quantity of total HMKEs per 1000 population there was a somewhat stronger but still moderate correlation (Tables 3 and 4). The partial correlation coefficients showed that, although in most of the cases the controlled variables had some effect on the strength of the relationship, this effect did not significantly modify the correlation.

The ranking of the settlements based on the settlements' complex indicators and the ranking according to the number * and power ** of HMKEs per 1000 population indicated a positive weak moderate correlation $\left({ }^{*} \rho=0.298 p=0.000 ;{ }^{* *} \rho=0.266 p=0.000\right)$.

There was a positive weak moderate correlation between the number of registered businesses per 1000 population, the number of businesses in the hospitality industry per 1000 population, and the power and number of residential HMKEs per 1000 population. The relationship between the number of residential HMKEs per 1000 population and the number of units of operating commercial accommodation units per 1000 population was also a weak moderate one. There was a stronger but still moderate positive correlation between the quantity and power of residential HMKEs per 1000 population and the number of residential electricity consumers per 1000 population, the number of electricity consumers per 1000 population, and the length of the low-voltage electricity distribution network per 1000 population (Appendix A Tables A1 and A2). The partial correlation coefficients showed that, although in most of the cases the controlled variables had some effect on the strength of the relationship, this effect did not significantly modify the correlation.

The ranking of the settlements based on the settlements' complex indicators and the ranking according to the number * and power ${ }^{* *}$ of residential HMKEs per 1000 population indicated a loose positive correlation $\left({ }^{*} \rho=0.188 p=0.000 ;{ }^{* *} \rho=0.155 p=0.000\right)$.

It was found that in the examined period, there was a positive weak moderate correlation between the number of registered businesses per 1000 population, the total budgetary revenue of the municipalities per 1000 population, the total budgetary expenditure of the municipalities per 1000 population and the quantity, and the power of business HMKEs per 1000 population. In addition, there was a weak moderate positive correlation between the quantity of business HMKEs per 1000 population and the number of electricity consumers per 1000 population and the length of the low-voltage electricity distribution network per 1000 population (Appendix A Tables A3 and A4). The partial correlation coefficients showed that, although in most of the cases the controlled variables had some effect on the strength of the relationship, this effect did not significantly modify the correlation. 


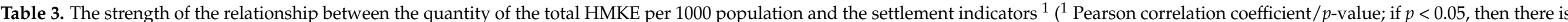

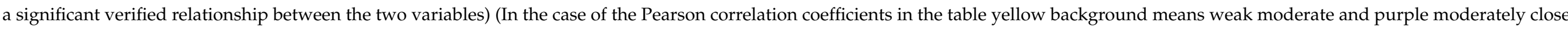

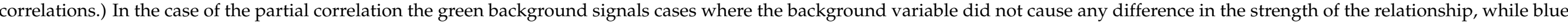
background indicates partial explanation (the controlled variable explains the relationship between variables $i$ and $j$ only partially), and black marking shows irrelevant comparison.

\begin{tabular}{|c|c|c|c|c|c|c|c|c|c|}
\hline \multirow[b]{2}{*}{ Indicator } & $\begin{array}{c}\text { Pearson } \\
\text { Correlation } \\
\text { Coefficient }\end{array}$ & \multicolumn{8}{|c|}{ Partial Correlation Coefficient } \\
\hline & $\begin{array}{l}\text { Total HMKEs } \\
\text { per } 1000 \text { Pop- } \\
\text { ulation } \\
\text { (pcs) }\end{array}$ & $\begin{array}{l}\text { Number of } \\
\text { Registered } \\
\text { Businesses } \\
\text { per } 1000 \text { Pop- } \\
\text { ulation } \\
\text { (pcs) }\end{array}$ & $\begin{array}{c}\text { Total Budgetary } \\
\text { Revenue of the } \\
\text { Municipalities } \\
\text { per } \\
\text { 1000 Population } \\
\text { (HUF 1000) }\end{array}$ & $\begin{array}{c}\text { Total Budgetary } \\
\text { Expenditure of } \\
\text { the } \\
\text { Municipalities } \\
\text { per } \\
\text { 1000 Population } \\
\text { (HUF 1000) }\end{array}$ & $\begin{array}{c}\text { Number of } \\
\text { Residential } \\
\text { Electricity } \\
\text { Consumers per } \\
1000 \text { Population } \\
\text { (pcs) }\end{array}$ & $\begin{array}{c}\text { Number of } \\
\text { Electricity } \\
\text { Consumers per } \\
1000 \text { Population } \\
\text { (pcs) }\end{array}$ & $\begin{array}{l}\text { Length of the } \\
\text { Low-Voltage } \\
\text { Electricity } \\
\text { Distribution } \\
\text { Network per } \\
1000 \text { Population } \\
(\mathrm{km})\end{array}$ & $\begin{array}{c}\text { Number of } \\
\text { Units of } \\
\text { Operating } \\
\text { Commercial Ac- } \\
\text { commodation } \\
\text { Units per } \\
1000 \text { Population } \\
\text { (pcs) }\end{array}$ & $\begin{array}{c}\text { Number of } \\
\text { Businesses in } \\
\text { the Hospitality } \\
\text { Industry per } \\
1000 \text { Population } \\
\text { (pcs) }\end{array}$ \\
\hline $\begin{array}{c}\text { Number of } \\
\text { registered } \\
\text { businesses per } \\
1000 \text { population } \\
\text { (pcs) }\end{array}$ & $0.365 / 0.000$ & & $0.160 / 0.000$ & $0.212 / 0.000$ & $0.436 / 0.000$ & $0.460 / 0.000$ & $0.393 / 0.000$ & $0.209 / 0.000$ & $0.208 / 0.000$ \\
\hline $\begin{array}{l}\text { Total budgetary } \\
\text { revenue of the } \\
\text { municipalities per } \\
1000 \text { population } \\
\text { (HUF 1000) }\end{array}$ & $0.215 / 0.000$ & $0.339 / 0.000$ & & $0.179 / 0.000$ & $0.470 / 0.000$ & $0.501 / 0.000$ & $0.441 / 0.000$ & $0.211 / 0.000$ & $0.215 / 0.000$ \\
\hline $\begin{array}{l}\text { Total budgetary } \\
\text { expenditure of the } \\
\text { municipalities per } \\
1000 \text { population } \\
\text { (HUF 1000) }\end{array}$ & $0.276 / 0.000$ & $0.323 / 0.000$ & $-0.017 / 0.000$ & & $0.460 / 0.000$ & $0.485 / 0.000$ & $0.429 / 0.000$ & $0.220 / 0.000$ & $0.210 / 0.000$ \\
\hline $\begin{array}{c}\text { Number of } \\
\text { residential } \\
\text { electricity } \\
\text { consumers per } \\
1000 \text { population } \\
\text { (pcs) } \\
\end{array}$ & $0.489 / 0.000$ & $0.277 / 0.000$ & $0.152 / 0.000$ & $0.207 / 0.000$ & & $0.220 / 0.000$ & $0.179 / 0.000$ & $0.243 / 0.000$ & $0.017 / 0.000$ \\
\hline
\end{tabular}


Table 3. Cont.

\begin{tabular}{|c|c|c|c|c|c|c|c|c|c|}
\hline \multirow[b]{2}{*}{ Indicator } & $\begin{array}{l}\text { Pearson } \\
\text { Correlation } \\
\text { Coefficient }\end{array}$ & \multicolumn{8}{|c|}{ Partial Correlation Coefficient } \\
\hline & $\begin{array}{l}\text { Total HMKEs } \\
\text { per } 1000 \text { Pop- } \\
\text { ulation } \\
\text { (pcs) }\end{array}$ & $\begin{array}{l}\text { Number of } \\
\text { Registered } \\
\text { Businesses } \\
\text { per } 1000 \text { Pop- } \\
\text { ulation } \\
\text { (pcs) }\end{array}$ & $\begin{array}{c}\text { Total Budgetary } \\
\text { Revenue of the } \\
\text { Municipalities } \\
\text { per } \\
\text { 1000 Population } \\
\text { (HUF 1000) }\end{array}$ & $\begin{array}{c}\text { Total Budgetary } \\
\text { Expenditure of } \\
\text { the } \\
\text { Municipalities } \\
\text { per } \\
\text { 1000 Population } \\
\text { (HUF 1000) }\end{array}$ & $\begin{array}{c}\text { Number of } \\
\text { Residential } \\
\text { Electricity } \\
\text { Consumers per } \\
1000 \text { Population } \\
\text { (pcs) }\end{array}$ & $\begin{array}{c}\text { Number of } \\
\text { Electricity } \\
\text { Consumers per } \\
1000 \text { Population } \\
\text { (pcs) }\end{array}$ & $\begin{array}{l}\text { Length of the } \\
\text { Low-Voltage } \\
\text { Electricity } \\
\text { Distribution } \\
\text { Network per } \\
1000 \text { Population } \\
(\mathrm{km})\end{array}$ & $\begin{array}{c}\text { Number of } \\
\text { Units of } \\
\text { Operating } \\
\text { Commercial Ac- } \\
\text { commodation } \\
\text { Units per } \\
1000 \text { Population } \\
\text { (pcs) }\end{array}$ & $\begin{array}{l}\text { Number of } \\
\text { Businesses in } \\
\text { the Hospitality } \\
\text { Industry per } \\
\text { 1000 Population } \\
\text { (pcs) }\end{array}$ \\
\hline $\begin{array}{c}\text { Number of } \\
\text { electricity } \\
\text { consumers per } \\
1000 \text { population } \\
\text { (pcs) }\end{array}$ & $0.523 / 0.000$ & $0.245 / 0.000$ & $0.129 / 0.000$ & $0.169 / 0.000$ & $-0.066 / 0.000$ & & $0.137 / 0.000$ & $0.154 / 0.000$ & $0.010 / 0.000$ \\
\hline $\begin{array}{l}\text { Length of the } \\
\text { low-voltage } \\
\text { electricity } \\
\text { distribution } \\
\text { network per } \\
1000 \text { population } \\
(\mathrm{km})\end{array}$ & $0.466 / 0.000$ & $0.254 / 0.000$ & $0.137 / 0.000$ & $0.194 / 0.000$ & $0.245 / 0.000$ & $0.299 / 0.000$ & & $0.240 / 0.000$ & $0.138 / 0.000$ \\
\hline $\begin{array}{l}\text { Number of units of } \\
\text { operating } \\
\text { commercial } \\
\text { accommodation } \\
\text { units per } \\
1000 \text { population } \\
\text { (pcs) }\end{array}$ & $0.243 / 0.000$ & $0.345 / 0.000$ & $0.176 / 0.000$ & $0.242 / 0.000$ & $0.445 / 0.000$ & $0.482 / 0.000$ & $0.430 / 0.000$ & & $0.135 / 0.000$ \\
\hline $\begin{array}{c}\text { Number of } \\
\text { businesses in the } \\
\text { hospitality } \\
\text { industry per } \\
1000 \text { population } \\
\text { (pcs) }\end{array}$ & $0.252 / 0.000$ & $0.339 / 0.000$ & $0.169 / 0.000$ & $0.239 / 0.000$ & $0.434 / 0.000$ & $0.473 / 0.000$ & $0.424 / 0.000$ & $0.119 / 0.000$ & \\
\hline
\end{tabular}




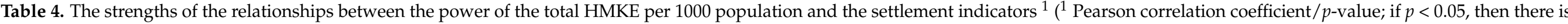

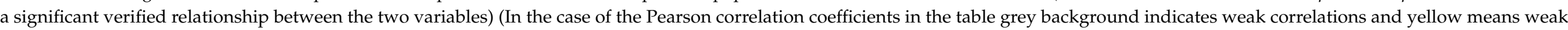

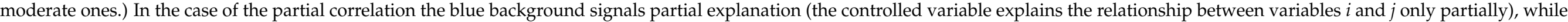
the black one shows irrelevant comparison.

\begin{tabular}{|c|c|c|c|c|c|c|c|c|}
\hline \multirow[b]{2}{*}{ Indicator } & \multirow{2}{*}{ 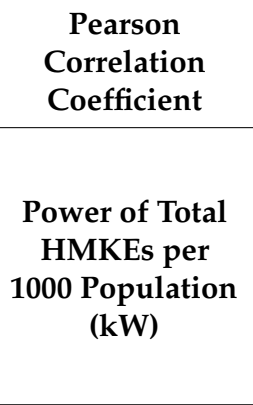 } & \multicolumn{7}{|c|}{ Partial Correlation Coefficient } \\
\hline & & $\begin{array}{c}\text { Number of } \\
\text { Registered } \\
\text { Businesses per } \\
1000 \text { Population } \\
\text { (pcs) }\end{array}$ & $\begin{array}{c}\text { Total Budgetary } \\
\text { Revenue of the } \\
\text { Municipalities } \\
\text { per } \\
\text { 1000 Population } \\
\text { (HUF 1000) }\end{array}$ & $\begin{array}{c}\text { Total Budgetary } \\
\text { Expenditure of } \\
\text { the } \\
\text { Municipalities } \\
\text { per } \\
\text { 1000 Population } \\
\text { (HUF 1000) }\end{array}$ & $\begin{array}{c}\text { Number of } \\
\text { Residential } \\
\text { Electricity } \\
\text { Consumers per } \\
1000 \text { Population } \\
\text { (pcs) }\end{array}$ & $\begin{array}{c}\text { Number of } \\
\text { Electricity } \\
\text { Consumers per } \\
1000 \text { Population } \\
\text { (pcs) }\end{array}$ & $\begin{array}{l}\text { Length of the } \\
\text { Low-Voltage } \\
\text { Electricity } \\
\text { Distribution } \\
\text { Network per } \\
1000 \text { Population } \\
(\mathrm{km})\end{array}$ & $\begin{array}{c}\text { Number of } \\
\text { Businesses in the } \\
\text { Hospitality } \\
\text { Industry per } \\
1000 \text { Population } \\
\text { (pcs) }\end{array}$ \\
\hline $\begin{array}{c}\text { Number of } \\
\text { registered } \\
\text { businesses per } \\
1000 \text { population } \\
\text { (pcs) }\end{array}$ & $0.350 / 0.000$ & & $0.149 / 0.000$ & $0.191 / 0.000$ & $0.301 / 0.000$ & $0.323 / 0.000$ & $0.291 / 0.000$ & $0.168 / 0.000$ \\
\hline $\begin{array}{c}\text { Total budgetary } \\
\text { revenue of the } \\
\text { municipalities } \\
\text { per } \\
1000 \text { population } \\
\text { (HUF 1000) }\end{array}$ & $0.203 / 0.000$ & $0.324 / 0.000$ & & $0.159 / 0.000$ & $0.344 / 0.000$ & $0.372 / 0.000$ & $0.345 / 0.000$ & $0.176 / 0.000$ \\
\hline $\begin{array}{c}\text { Total budgetary } \\
\text { expenditure of } \\
\text { the } \\
\text { municipalities } \\
\text { per } \\
1000 \text { population } \\
\text { (HUF 1000) }\end{array}$ & $0.255 / 0.000$ & $0.309 / 0.000$ & $-0.008 / 0.688$ & & $0.332 / 0.000$ & $0.355 / 0.000$ & $0.333 / 0.000$ & $0.172 / 0.000$ \\
\hline $\begin{array}{c}\text { Number of } \\
\text { residential } \\
\text { electricity } \\
\text { consumers per } \\
1000 \text { population } \\
\text { (pcs) }\end{array}$ & $0.366 / 0.000$ & $0.280 / 0.000$ & $0.152 / 0.000$ & $0.198 / 0.000$ & & $0.184 / 0.000$ & $0.164 / 0.000$ & $0.042 / 0.000$ \\
\hline
\end{tabular}


Table 4. Cont.

\begin{tabular}{|c|c|c|c|c|c|c|c|c|}
\hline \multirow[b]{2}{*}{ Indicator } & \multirow{2}{*}{$\begin{array}{c}\text { Pearson } \\
\text { Correlation } \\
\text { Coefficient } \\
\\
\text { Power of Total } \\
\text { HMKEs per } \\
1000 \text { Population } \\
(\mathrm{kW})\end{array}$} & \multicolumn{7}{|c|}{ Partial Correlation Coefficient } \\
\hline & & $\begin{array}{c}\text { Number of } \\
\text { Registered } \\
\text { Businesses per } \\
1000 \text { Population } \\
\text { (pcs) }\end{array}$ & $\begin{array}{c}\text { Total Budgetary } \\
\text { Revenue of the } \\
\text { Municipalities } \\
\text { per } \\
\text { 1000 Population } \\
\text { (HUF 1000) }\end{array}$ & $\begin{array}{c}\text { Total Budgetary } \\
\text { Expenditure of } \\
\text { the } \\
\text { Municipalities } \\
\text { per } \\
\text { 1000 Population } \\
\text { (HUF 1000) }\end{array}$ & $\begin{array}{c}\text { Number of } \\
\text { Residential } \\
\text { Electricity } \\
\text { Consumers per } \\
1000 \text { Population } \\
\text { (pcs) }\end{array}$ & $\begin{array}{c}\text { Number of } \\
\text { Electricity } \\
\text { Consumers per } \\
1000 \text { Population } \\
\text { (pcs) }\end{array}$ & $\begin{array}{c}\text { Length of the } \\
\text { Low-Voltage } \\
\text { Electricity } \\
\text { Distribution } \\
\text { Network per } \\
1000 \text { Population } \\
\text { (km) }\end{array}$ & $\begin{array}{c}\text { Number of } \\
\text { Businesses in the } \\
\text { Hospitality } \\
\text { Industry per } \\
1000 \text { Population } \\
\text { (pcs) }\end{array}$ \\
\hline $\begin{array}{c}\text { Number of } \\
\text { electricity } \\
\text { consumers per } \\
1000 \text { population } \\
\text { (pcs) }\end{array}$ & $0.398 / 0.000$ & $0.256 / 0.000$ & $0.135 / 0.000$ & $0.170 / 0.000$ & $-0.075 / 0.000$ & & $0.126 / 0.000$ & $0.033 / 0.000$ \\
\hline $\begin{array}{l}\text { Length of the } \\
\text { low-voltage } \\
\text { electricity } \\
\text { distribution } \\
\text { network per } \\
1000 \text { population } \\
(\mathrm{km})\end{array}$ & $0.373 / 0.000$ & $0.260 / 0.000$ & $0.138 / 0.000$ & $0.185 / 0.000$ & $0.147 / 0.000$ & $0.196 / 0.000$ & & $0.118 / 0.000$ \\
\hline $\begin{array}{l}\text { Number of units } \\
\text { of operating } \\
\text { commercial } \\
\text { accommodation } \\
\text { units per } \\
1000 \text { population } \\
\text { (pcs) }\end{array}$ & $0.183 / 0.000$ & $0.334 / 0.000$ & $0.173 / 0.000$ & $0.228 / 0.000$ & $0.328 / 0.000$ & $0.364 / 0.000$ & $0.343 / 0.000$ & $0.131 / 0.000$ \\
\hline $\begin{array}{c}\text { Number of } \\
\text { businesses in the } \\
\text { hospitality } \\
\text { industry per } \\
1000 \text { population } \\
\text { (pcs) }\end{array}$ & $0.213 / 0.000$ & $0.327 / 0.000$ & $0.164 / 0.000$ & $0.223 / 0.000$ & $0.308 / 0.000$ & $0.346 / 0.000$ & $0.333 / 0.000$ & \\
\hline
\end{tabular}


The ranking of the settlements based on the settlements' complex indicators and the ranking according to the number * and power ** of business HMKEs per 1000 population indicated a positive weak moderate correlation $\left({ }^{*} \rho=0.203 p=0.000\right.$; ${ }^{* *} \rho=0.193 p=0.000$ ).

For more detailed research results, analyses were carried out regarding the 1763 settlements where EON is the electricity supplier, examining the HMKE quantity and power per 1000 population data in total but also at residential, business, and public levels.

It was established that concerning the settlements in the examined period, there was a positive weak moderate correlation between the number of registered businesses per 1000 population, the length of the low-voltage electricity distribution network per 1000 population, the number of businesses in the hospitality industry per 1000 population, and the power and number of all HMKEs per 1000 population. Relationships of the same direction and similar strength were detected between the number of operating commercial accommodation units per 1000 population and the number of total HMKEs per 1000 population; and the total budgetary expenditure of the municipalities per 1000 population, the number of residential electricity consumers per 1000 population, and the power of total HMKEs per 1000 population. A still moderate but somewhat stronger correlation was found between the number of residential electricity consumers per 1000 population, the number of electricity consumers per 1000 population, and the quantity of total HMKEs per 1000 population (Tables 5 and 6). The partial correlation coefficients showed that, although in most of the cases the controlled variables had some effect on the strength of the relationship, this effect did not significantly modify the correlation.

The ranking of the settlements based on the settlements' complex indicators, which were created based on the settlements' indicators, and the ranking according to the number * and power ${ }^{* *}$ of total HMKEs per 1000 population indicated a positive weak moderate correlation $\left({ }^{*} \rho=0.208 p=0.000 ;{ }^{* *} \rho=0.244 p=0.000\right)$.

There was a positive weak moderately close correlation between the number of registered businesses per 1000 population, the length of the low-voltage electricity distribution network per 1000 population, the number of businesses in the hospitality industry per 1000 population, and the quantity and power of residential HMKEs per 1000 population. The relationship between the number of residential HMKEs per 1000 population and the number of units of operating commercial accommodation units per 1000 population was also a positive weak moderate one. A still moderate but somewhat stronger correlation was observed between the number of residential electricity consumers per 1000 population, the number of electricity consumers per 1000 population, and the quantity and power of residential HMKEs per 1000 population (Appendix A Tables A5 and A6). The partial correlation coefficients showed that, although in most of the cases the controlled variables had some effect on the strength of the relationship, this effect did not significantly modify the correlation.

The ranking of the settlements based on the settlements' complex indicators and the ranking according to the number * and power ${ }^{* *}$ of residential HMKEs per 1000 population indicated a loose positive correlation $\left({ }^{*} \rho=0.133 p=0.000 ;{ }^{* *} \rho=0.117 p=0.000\right)$.

It was found that in the examined period, there was a positive weak moderate correlation between the total budgetary revenue of the municipalities per 1000 population, the total budgetary expenditure of the municipalities per 1000 population, and the quantity and power of public HMKEs per 1000 population (Appendix A Tables A7 and A8). The partial correlation coefficients showed that, although in most of the cases the controlled variables had some effect on the strength of the relationship, this effect did not significantly modify the correlation.

The ranking of the settlements based on the settlements' complex indicators and the ranking according to the number * and power ** of public HMKEs per 1000 population indicated a positive weak correlation $\left({ }^{*} \rho=0.103 p=0.000 ;{ }^{* *} \rho=0.139 p=0.000\right)$. 


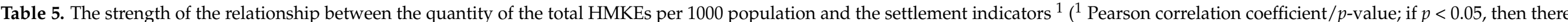

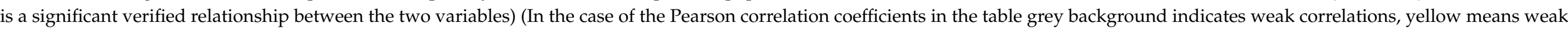

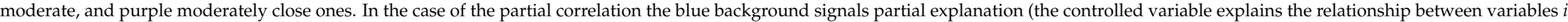
and $j$ only partially), while the black one shows irrelevant comparison.

\begin{tabular}{|c|c|c|c|c|c|c|c|}
\hline \multirow[b]{2}{*}{ Indicator } & $\begin{array}{l}\text { Pearson } \\
\text { Correlation } \\
\text { Coefficient }\end{array}$ & \multicolumn{6}{|c|}{ Partial Correlation Coefficient } \\
\hline & $\begin{array}{l}\text { Total HMKEs per } \\
1000 \text { Population } \\
\text { (pcs) }\end{array}$ & $\begin{array}{c}\text { Number of } \\
\text { Residential } \\
\text { Electricity } \\
\text { Consumers per } \\
1000 \text { Population } \\
\text { (pcs) }\end{array}$ & $\begin{array}{c}\text { Number of } \\
\text { Electricity } \\
\text { Consumers per } \\
1000 \text { Population } \\
\text { (pcs) }\end{array}$ & $\begin{array}{c}\text { Number of } \\
\text { Registered } \\
\text { Businesses per } \\
1000 \text { Population } \\
\text { (pcs) }\end{array}$ & $\begin{array}{l}\text { Length of the } \\
\text { Low-Voltage } \\
\text { Electricity } \\
\text { Distribution } \\
\text { Network per } \\
1000 \text { Population } \\
(\mathrm{km})\end{array}$ & $\begin{array}{c}\text { Number of Units of } \\
\text { Operating } \\
\text { Commercial } \\
\text { Accommodation } \\
\text { Units per } \\
1000 \text { Population } \\
\text { (pcs) }\end{array}$ & $\begin{array}{c}\text { Number of } \\
\text { Businesses in the } \\
\text { Hospitality } \\
\text { Industry per } \\
1000 \text { Population } \\
\text { (pcs) }\end{array}$ \\
\hline $\begin{array}{c}\text { Number of registered } \\
\text { businesses per } \\
1000 \text { population (pcs) }\end{array}$ & $0.222 / 0.000$ & $0.378 / 0.000$ & $0.382 / 0.000$ & & $0.194 / 0.000$ & $0.197 / 0.000$ & $0.320 / 0.000$ \\
\hline $\begin{array}{l}\text { Total budgetary revenue } \\
\text { of the municipalities per } \\
1000 \text { population } \\
\text { (HUF 1000) }\end{array}$ & $0.158 / 0.000$ & $0.395 / 0.000$ & $0.400 / 0.000$ & $0.201 / 0.000$ & $0.226 / 0.000$ & $0.203 / 0.000$ & $0.319 / 0.000$ \\
\hline $\begin{array}{l}\text { Total budgetary } \\
\text { expenditure of the } \\
\text { municipalities per } \\
1000 \text { population } \\
\text { (HUF 1000) }\end{array}$ & $0.169 / 0.000$ & $0.394 / 0.000$ & $0.398 / 0.000$ & $0.196 / 0.000$ & $0.226 / 0.000$ & $0.198 / 0.000$ & $0.318 / 0.000$ \\
\hline $\begin{array}{l}\text { Number of residential } \\
\text { electricity consumers per } \\
1000 \text { population (pcs) }\end{array}$ & $0.411 / 0.000$ & & $0.109 / 0.000$ & $0.142 / 0.000$ & $-0.085 / 0.000$ & $0.086 / 0.000$ & $0.171 / 0.000$ \\
\hline $\begin{array}{c}\text { Number of electricity } \\
\text { consumers per } \\
1000 \text { population (pcs) }\end{array}$ & $0.417 / 0.000$ & $-0.074 / 0.002$ & & $0.131 / 0.000$ & $-0.104 / 0.000$ & $0.077 / 0.000$ & $0.163 / 0.000$ \\
\hline
\end{tabular}


Table 5. Cont.

\begin{tabular}{|c|c|c|c|c|c|c|c|}
\hline \multirow[b]{2}{*}{ Indicator } & \multirow{2}{*}{$\begin{array}{c}\text { Pearson Correlation } \\
\text { Coefficient }\end{array}$} & \multicolumn{6}{|c|}{ Partial Correlation Coefficient } \\
\hline & & $\begin{array}{c}\text { Number of } \\
\text { Residential } \\
\text { Electricity } \\
\text { Consumers per } \\
1000 \text { Population } \\
\text { (pcs) }\end{array}$ & $\begin{array}{c}\text { Number of } \\
\text { Electricity } \\
\text { Consumers per } \\
1000 \text { Population } \\
\text { (pcs) }\end{array}$ & $\begin{array}{c}\text { Number of } \\
\text { Registered } \\
\text { Businesses per } \\
1000 \text { Population } \\
\text { (pcs) }\end{array}$ & $\begin{array}{l}\text { Length of the } \\
\text { Low-Voltage } \\
\text { Electricity } \\
\text { Distribution } \\
\text { Network per } \\
1000 \text { Population } \\
(\mathrm{km})\end{array}$ & $\begin{array}{c}\text { Number of Units of } \\
\text { Operating } \\
\text { Commercial } \\
\text { Accommodation } \\
\text { Units per } \\
1000 \text { Population } \\
\text { (pcs) }\end{array}$ & $\begin{array}{c}\text { Number of } \\
\text { Businesses in the } \\
\text { Hospitality Industry } \\
\text { per } 1000 \text { Population } \\
\text { (pcs) }\end{array}$ \\
\hline $\begin{array}{c}\text { Number of units of } \\
\text { operating } \\
\text { commercial } \\
\text { accommodation } \\
\text { units per } \\
1000 \text { population } \\
\text { (pcs) }\end{array}$ & $0.227 / 0.000$ & $0.360 / 0.000$ & $0.366 / 0.000$ & $0.191 / 0.000$ & $0.203 / 0.000$ & & $0.268 / 0.000$ \\
\hline $\begin{array}{c}\text { Number of } \\
\text { businesses in the } \\
\text { hospitality industry } \\
\text { per } 1000 \text { population } \\
\text { (pcs) }\end{array}$ & $0.345 / 0.000$ & $0.289 / 0.000$ & $0.296 / .000$ & $0.178 / 0.000$ & $0.161 / 0.000$ & $0.024 / 0.000$ & \\
\hline
\end{tabular}




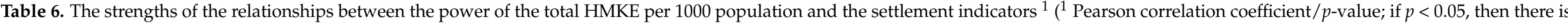

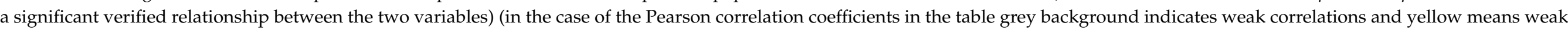

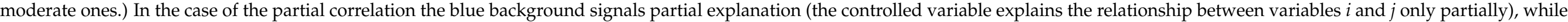
the black one shows irrelevant comparison.

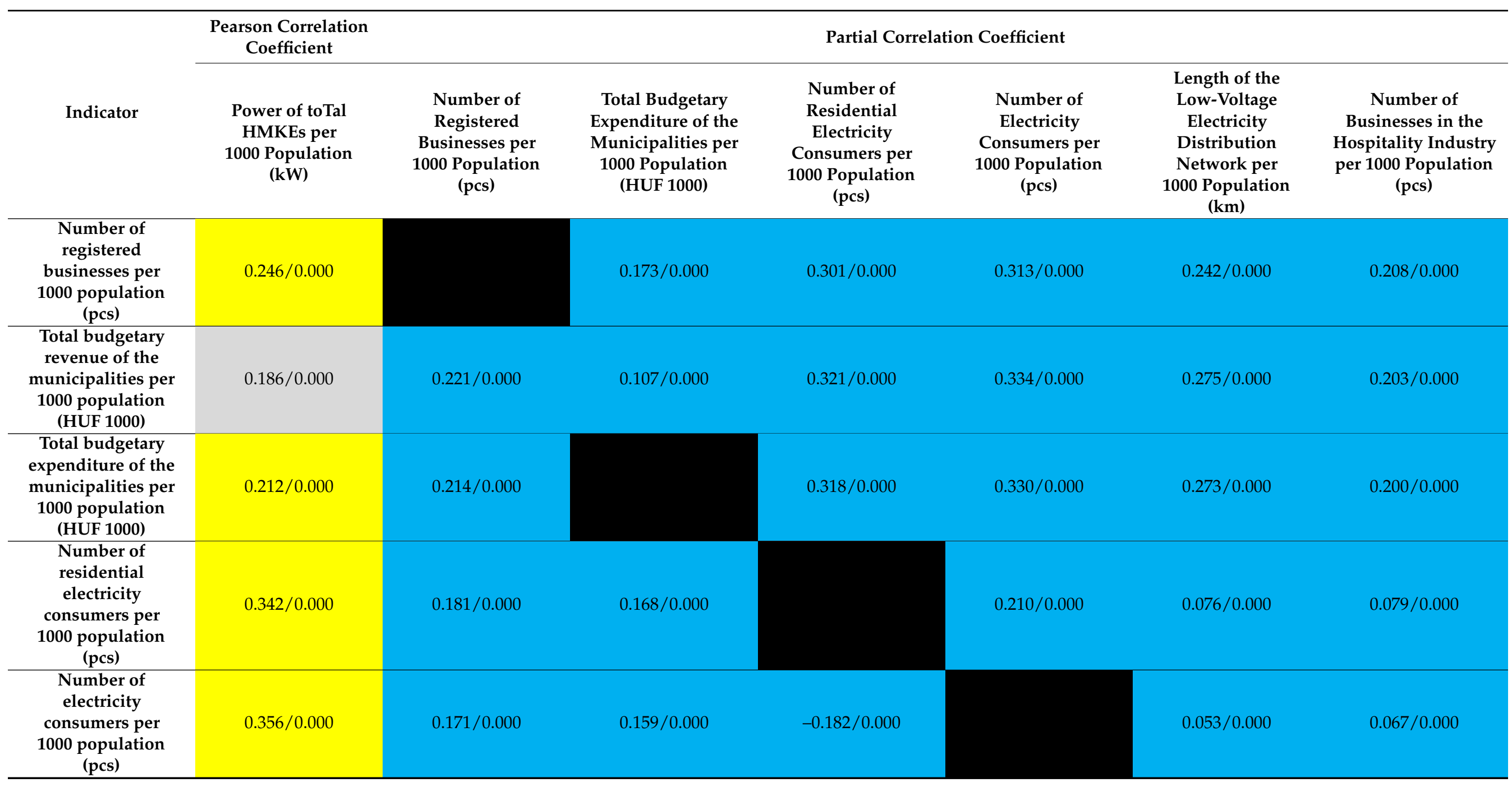


Table 6. Cont.

\begin{tabular}{|c|c|c|c|c|c|c|c|}
\hline \multirow[b]{2}{*}{ Indicator } & \multirow{2}{*}{$\begin{array}{c}\begin{array}{c}\text { Pearson Correlation } \\
\text { Coefficient }\end{array} \\
\\
\text { Power of toTal } \\
\text { HMKEs per } \\
1000 \text { Population } \\
\text { (kW) }\end{array}$} & \multicolumn{6}{|c|}{ Partial Correlation Coefficient } \\
\hline & & $\begin{array}{c}\text { Number of } \\
\text { Registered } \\
\text { Businesses per } \\
\text { 1000 Population } \\
\text { (pcs) }\end{array}$ & $\begin{array}{l}\text { Total Budgetary } \\
\text { Expenditure of the } \\
\text { Municipalities per } \\
\text { 1000 Population } \\
\text { (HUF 1000) }\end{array}$ & $\begin{array}{c}\text { Number of } \\
\text { Residential } \\
\text { Electricity } \\
\text { Consumers per } \\
1000 \text { Population } \\
\text { (pcs) }\end{array}$ & $\begin{array}{c}\text { Number of } \\
\text { Electricity } \\
\text { Consumers per } \\
1000 \text { Population } \\
\text { (pcs) }\end{array}$ & $\begin{array}{c}\text { Length of the } \\
\text { Low-Voltage } \\
\text { Electricity } \\
\text { Distribution } \\
\text { Network per } \\
1000 \text { Population } \\
(\mathbf{k m})\end{array}$ & $\begin{array}{c}\text { Number of } \\
\text { Businesses in the } \\
\text { Hospitality Industry } \\
\text { per } 1000 \text { Population } \\
\text { (pcs) }\end{array}$ \\
\hline $\begin{array}{c}\text { Number of units of } \\
\text { operating } \\
\text { commercial } \\
\text { accommodation } \\
\text { units per } \\
1000 \text { population } \\
\text { (pcs) }\end{array}$ & $0.178 / 0.000$ & $0.222 / 0.000$ & $0.181 / 0.000$ & $0.302 / 0.000$ & $0.317 / 0.000$ & $0.267 / 0.000$ & $0.169 / 0.000$ \\
\hline $\begin{array}{c}\text { Number of } \\
\text { businesses in the } \\
\text { hospitality industry } \\
\text { per } 1000 \text { population } \\
\text { (pcs) }\end{array}$ & $0.240 / 0.000$ & $0.215 / 0.000$ & $0.164 / 0.000$ & $0.262 / 0.000$ & $0.279 / 0.000$ & $0.245 / 0.000$ & \\
\hline
\end{tabular}


In the examined period, there was a positive weak moderate relationship between the number of registered businesses per 1000 population, the number of units of operating commercial accommodation units per 1000 population, and the quantity of business HMKEs per 1000 population. The power of business HMKEs per 1000 population did not show any close correlation with any of the settlement indicators. However, there was a positive but weak correlation between the number of registered businesses per 1000 population, the total budgetary revenue of the municipalities per 1000 population, the total budgetary expenditure of the municipalities per 1000 population, the number of residential electricity consumers per 1000 population, the number of electricity consumers per 1000 population, the length of the low-voltage electricity distribution network per 1000 population, the number of operating units of commercial accommodation units per 1000 population, the number of businesses in the hospitality industry per 1000 population, and the power of business HMKEs per 1000 population (Appendix A Tables A9 and A10). The partial correlation coefficients showed that, although in most of the cases the controlled variables had some effect on the strength of the relationship, this effect did not significantly modify the correlation.

The ranking of the settlements based on the settlements' complex indicators, which were created on the basis of the settlement indicators, and the ranking according to the number $^{*}$ and power ${ }^{* *}$ of business HMKEs indicated a positive weak correlation $\left({ }^{*} \rho=0.128\right.$ $\left.p=0.000 ;{ }^{* *} \rho=0.141 p=0.000\right)$.

At the beginning of the study, three hypotheses were formulated, and they were confirmed, as shown below. The following points were proven:

- $\quad$ There are certain settlement indicators each of which individually shows a correlation with the quantity and power of photovoltaic HMKEs. These relationships could be identified irrespective of the service regions of the specific electricity suppliers. There was a moderately strong correlation between the number of registered economic organizations per 1000 population, the number of operating commercial accommodation units per 1000 population, the number of businesses in the hospitality industry per 1000 population, and the quantity of total photovoltaic HMKEs per 1000 population. Furthermore, there was also a moderately strong correlation between the total budgetary expenditure of the municipalities per 1000 population, the number of businesses in the hospitality industry per 1000 population, the number of residential electricity consumers per 1000 population, the number of electricity consumers per 1000 population, the length of the low-voltage electricity distribution network per 1000 population, and the power of total photovoltaic HMKEs per 1000 population.

- The ranking of the settlements based on the complex indicator created from the settlement indicators showed a correlation with the ranking of the settlements according to the number and power of the photovoltaic HMKEs per 1000 population. The relationship between the rankings was moderately strong, with the exception of the residential, public, and business photovoltaic HMKE users in the service region of EON, where the correlation was only weak.

- A regression model was created from the settlements' database containing data from all three electricity supplier regions. In this model, the quantity of photovoltaic HMKEs per 1000 population is explained by the number of electricity consumers per 1000 population, the number of economic organizations per 1000 population, and the total budgetary expenditure of the municipalities per 1000 population.

\section{Conclusions}

Based on the results of this study, it was established that according to the analyses from all three examination aspects (settlements with ELMÚ-ÉMÁSZ, EON, NKM or ELMÚ-ÉMÁSZ, EON, or only EON as the suppliers of electricity) there was a positive weak moderate correlation between the settlements' indicators of the number of registered businesses per 1000 population, the number of operating commercial accommodation units per 1000 population, the number of businesses in the hospitality industry per 1000 pop- 
ulation, and the number of total photovoltaic HMKEs per 1000 population. Between the number of residential electricity consumers per 1000 population, the number of electricity consumers per 1000 population, and the quantity of total photovoltaic HMKEs, there was a somewhat stronger but still moderate correlation regardless whether the electricity supply regions of ELMÜ-ÉMÁSZ and EON or only those of EON were considered. Additionally, in these two types of electricity supply regions (ELMÜ-ÉMÁSZ and EON or only EON), there was a weak moderate correlation between the total budgetary expenditure of the municipalities per 1000 population, the number of businesses in the hospitality industry per 1000 population, the number of residential electricity consumers per 1000 population, the number of electricity consumers per 1000 population, the length of the low-voltage electricity distribution network per 1000 population, and the total power of photovoltaic HMKEs per 1000 population.

The investigations also highlighted that in the regions where ELMÚ-ÉMÁSZ and EON or only EON were the suppliers of electricity, there was a positive weak moderate correlation between the number of registered businesses per 1000 population, the number of businesses in the hospitality industry per 1000 population, the number of operating commercial accommodation units per 1000 population, and the quantity of residential photovoltaic HMKEs per 1000 population. The strength of the correlation between the number of registered businesses per 1000 population, the number of businesses in the hospitality industry per 1000 population, and the power of residential photovoltaic HMKEs per 1000 population was also positive weak moderate. There was a stronger but still moderate positive correlation between the quantity and power of residential photovoltaic HMKEs per 1000 population and the number of residential electricity consumers per 1000 population and the number of electricity consumers per 1000 population.

According to our results, the business photovoltaic HMKEs per 1000 population showed a positive weak moderate relationship with the number of registered businesses per 1000 population regardless of the regions of electricity supply. Furthermore, it was found that in the region of the EON electric company, there was also a positive weak moderate correlation between the total budgetary revenue of the municipalities per 1000 population, the total budgetary expenditure of the municipalities per 1000 population, and the quantity and power of public photovoltaic HMKEs per 1000 population.

It was established that the rankings of the settlements based on the settlements' complex indicators, which were created based on the settlement indicators, and the rankings according to the number and power of (total, residential, business) photovoltaic HMKEs per 1000 population indicated a positive loose correlation regardless of the electric companies regions.

Having analyzed the settlements of the three electricity companies' service regions, it can be stated that it is possible to describe the quantity of photovoltaic HMKEs per 1000 population with a regression model, in which the following settlement indicators can be regarded as explanatory factors: the number of electricity consumers per 1000 population, the number of registered economic organizations per 1000 population, and the total budgetary expenditure of the municipalities per 1000 population.

The usefulness of the results of this study is diverse. On the one hand, it may be of help with the planning of energy policy and energy strategy in terms of identifying the factors playing a part in the spread of photovoltaic HMKEs, while, on the other hand, it can inspire scientists to continue the research in this field. The objectives of such future investigations will involve the examination of other regional levels (NUTS 3, LAU 1), and processing data from 2020 will also allow the observation of changes over time.

Author Contributions: N.H.B. was mainly responsible for the technical, experimental and modelling aspects, and conceived and designed the manuscript. All authors contributed equally in the analysis of the data and the writing and revision of the manuscript. All authors have read and agreed to the published version of the manuscript.

Funding: This research was funded by Szechenyi 2020 under the EFOP-3.6.1-16-2016-00015. 
Acknowledgments: We acknowledge the financial support of Széchenyi 2020 under the EFOP-3.6.116-2016-00015.

Conflicts of Interest: The authors declare no conflict of interest.

Abbreviations
$\begin{array}{ll}\text { The following abbreviations are used in this manuscript: } \\ \text { ELMÚ- } & \text { ELMÚ-ÉMÁSZ Energiaszolgáltató ZRT./ELMÚ-ÉMÁSZ Energy Service } \\ \text { ÉMÁSZ } & \text { Privately Held Company/ } \\ \text { EON } & \text { E.ON Hungária Zrt./E.ON Hungária Privately Held Company/ } \\ f a_{i j} & \text { normalized basic indicator } \\ \text { HMKE } & \text { household-sized power plants } \\ \text { CDI } & \text { complex development index } \\ \text { KSH } & \text { Központi Statisztikai Hivatal/Hungarian Central Statistical Office/ } \\ \min \left(f a_{i j}\right) & \text { the lowest value of the basic indicator } \\ \text { max }\left(f a_{i j}\right) & \text { the highest value of the basic indicator } \\ \text { NKM } & \text { NKM Energia Zrt./NKM Energia Privately Held Company/ } \\ \text { pSi } & \text { Polycrystalline } \\ \text { PV } & \text { Photovoltaic } \\ \text { TEIR } & \text { Országos Teületfejlesztési és Területrendezési Információs Rendszer/National } \\ x_{1} \text { to } x_{n} & \text { Regional Development and Spatial Planning Information System/ } \\ \beta_{1} & \text { Represent independent variables } \\ \beta_{\mathrm{n}} & \text { The regression coefficient of variable } x_{1}\end{array}$
$\begin{array}{ll}\text { The regression coefficient of variable } x_{n} .\end{array}$




\section{Appendix A Correlations between the Quantity and Power of the Residential, Business, and Public HMKEs and the Development Indicators}

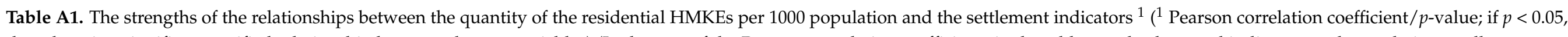

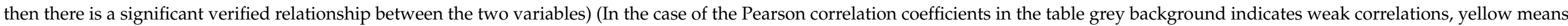

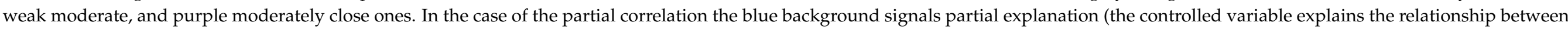
variables $i$ and $j$ only partially), while the black one shows irrelevant comparison.).

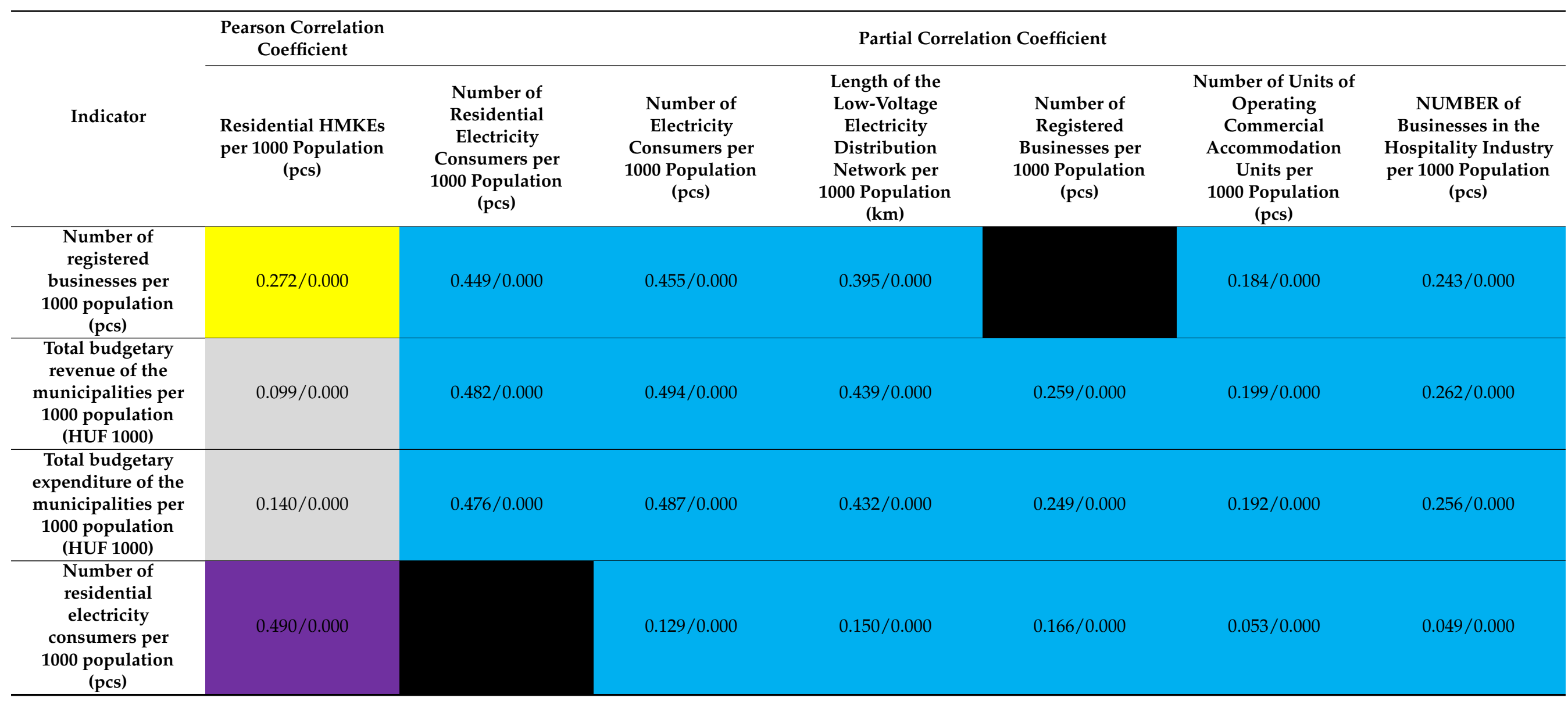


Table A1. Cont.

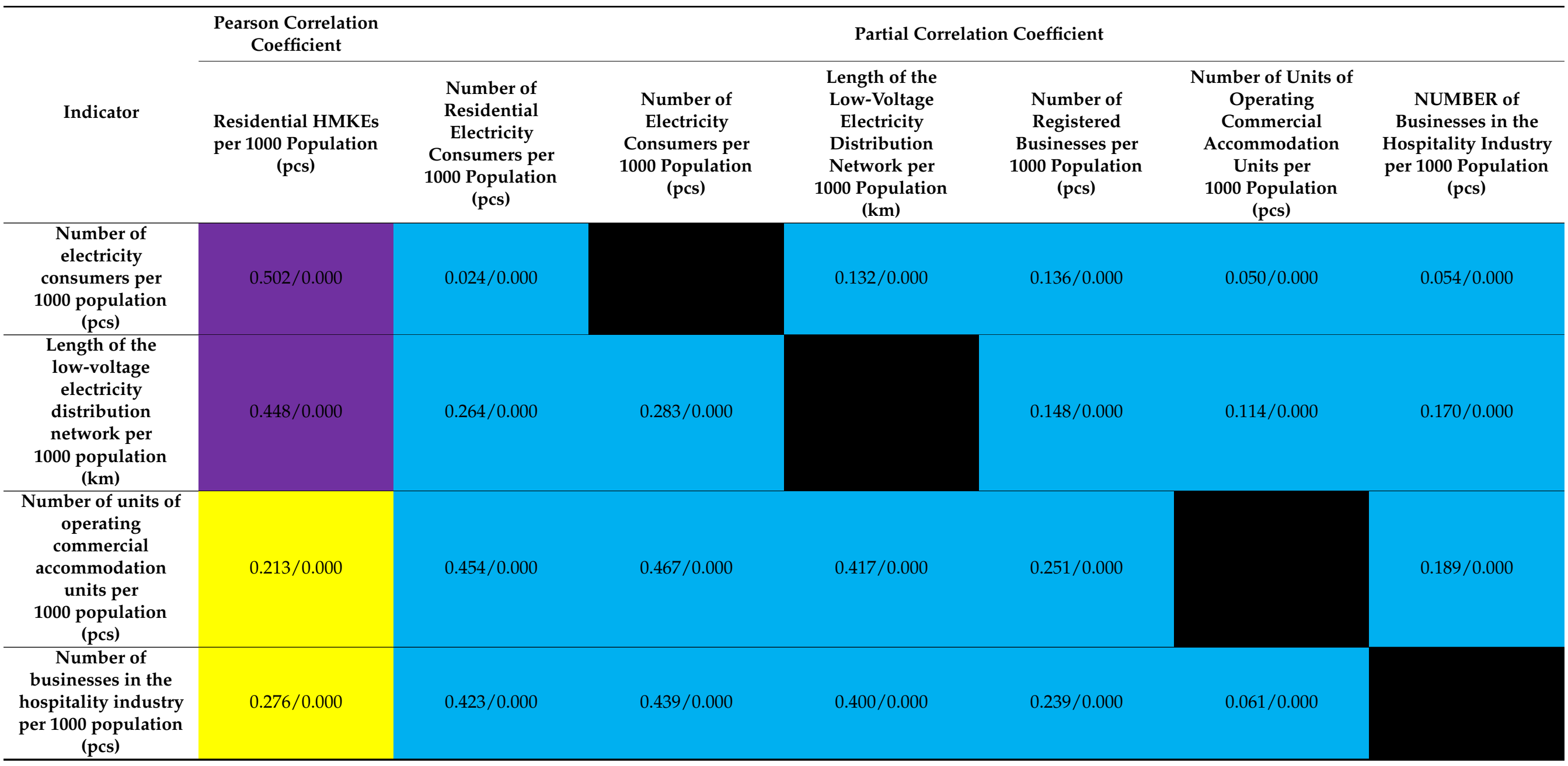




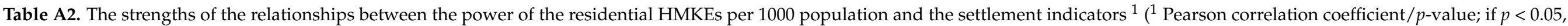

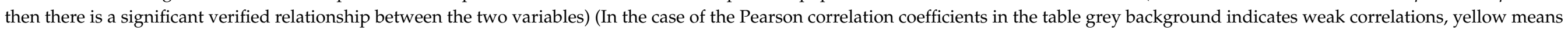

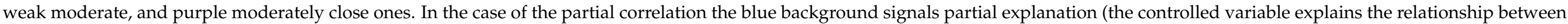
variables $i$ and $j$ only partially), while the black one shows irrelevant comparison.).

\begin{tabular}{|c|c|c|c|c|c|c|}
\hline \multirow[b]{2}{*}{ Indicator } & \multirow{2}{*}{$\begin{array}{c}\begin{array}{c}\text { Pearson Correlation } \\
\text { Coefficient }\end{array} \\
\begin{array}{c}\text { Residential HMKE } \\
\text { Power per }\end{array} \\
1000 \text { Population }(\mathrm{kW})\end{array}$} & \multicolumn{5}{|c|}{ Partial Correlation Coefficient } \\
\hline & & $\begin{array}{c}\text { Number of Residential } \\
\text { Electricity Consumers } \\
\text { per } 1000 \text { Population } \\
\text { (pcs) }\end{array}$ & $\begin{array}{l}\text { Number of Electricity } \\
\text { Consumers per } \\
1000 \text { Population (pcs) }\end{array}$ & $\begin{array}{l}\text { Length of the } \\
\text { Low-Voltage Electricity } \\
\text { Distribution Network } \\
\text { per } 1000 \text { Population } \\
(\mathbf{k m})\end{array}$ & $\begin{array}{c}\text { Number of Registered } \\
\text { Businesses per } \\
1000 \text { Population (pcs) }\end{array}$ & $\begin{array}{l}\text { Number of Businesses } \\
\text { in the Hospitality } \\
\text { Industry per } \\
1000 \text { Population (pcs) }\end{array}$ \\
\hline $\begin{array}{c}\text { Number of registered } \\
\text { businesses per } \\
1000 \text { population (pcs) }\end{array}$ & $0.274 / 0.000$ & $0.362 / 0.000$ & $0.385 / 0.000$ & $0.347 / 0.000$ & & $0.183 / 0.000$ \\
\hline $\begin{array}{l}\text { Total budgetary } \\
\text { revenue of the } \\
\text { municipalities per } \\
1000 \text { population } \\
\text { (HUF 1000) }\end{array}$ & $0.078 / 0.000$ & $0.403 / 0.000$ & $0.433 / 0.000$ & $0.399 / 0.000$ & $0.265 / 0.000$ & $0.207 / 0.000$ \\
\hline $\begin{array}{l}\text { Total budgetary } \\
\text { expenditure of the } \\
\text { municipalities per } \\
1000 \text { population } \\
\text { (HUF 1000) }\end{array}$ & $0.115 / 0.000$ & $0.397 / 0.000$ & $0.426 / 0.000$ & $0.392 / 0.000$ & $0.256 / 0.000$ & $0.201 / 0.000$ \\
\hline $\begin{array}{c}\text { Number of residential } \\
\text { electricity consumers } \\
\text { per } 1000 \text { population } \\
\text { (pcs) }\end{array}$ & $0.409 / 0.000$ & & $0.183 / 0.000$ & $0.169 / 0.000$ & $0.185 / 0.000$ & $0.024 / 0.000$ \\
\hline $\begin{array}{c}\text { Number of electricity } \\
\text { consumers per } \\
1000 \text { population (pcs) }\end{array}$ & $0.439 / 0.000$ & $-0.059 / 0.000$ & & $0.133 / 0.000$ & $0.157 / 0.000$ & $0.017 / 0.000$ \\
\hline $\begin{array}{l}\text { Length of the } \\
\text { low-voltage electricity } \\
\text { distribution network } \\
\text { per } 1000 \text { population } \\
(\mathrm{km})\end{array}$ & $0.405 / 0.000$ & $0.180 / 0.000$ & $0.226 / 0.000$ & & $0.163 / 0.000$ & $0.115 / 0.000$ \\
\hline
\end{tabular}


Table A2. Cont.

\begin{tabular}{|c|c|c|c|c|c|c|}
\hline \multirow[b]{2}{*}{ Indicator } & $\begin{array}{c}\text { Pearson Correlation } \\
\text { Coefficient }\end{array}$ & \multicolumn{5}{|c|}{ Partial Correlation Coefficient } \\
\hline & $\begin{array}{c}\text { Residential HMKE } \\
\text { Power per } \\
1000 \text { Population }(\mathrm{kW})\end{array}$ & $\begin{array}{c}\text { Number of Residential } \\
\text { Electricity Consumers } \\
\text { per } 1000 \text { Population } \\
\text { (pcs) }\end{array}$ & $\begin{array}{l}\text { Number of Electricity } \\
\text { Consumers per } \\
1000 \text { Population (pcs) }\end{array}$ & $\begin{array}{c}\text { Length of the } \\
\text { Low-Voltage Electricity } \\
\text { Distribution Network } \\
\text { per } 1000 \text { Population } \\
(\mathrm{km})\end{array}$ & $\begin{array}{c}\text { Number of Registered } \\
\text { Businesses per } \\
1000 \text { Population (pcs) }\end{array}$ & $\begin{array}{c}\text { Number of Businesses } \\
\text { in the Hospitality } \\
\text { Industry per } \\
1000 \text { Population (pcs) }\end{array}$ \\
\hline $\begin{array}{l}\text { Number of units of } \\
\text { operating commercial } \\
\text { accommodation units } \\
\text { per } 1000 \text { population } \\
\text { (pcs) }\end{array}$ & $0.163 / 0.000$ & $0.381 / 0.000$ & $0.413 / 0.000$ & $0.381 / 0.000$ & $0.257 / 0.000$ & $0.153 / 0.000$ \\
\hline $\begin{array}{c}\text { Number of businesses } \\
\text { in the hospitality } \\
\text { industry per } \\
1000 \text { population (pcs) }\end{array}$ & $0.219 / 0.000$ & $0.395 / 0.000$ & $0.390 / 0.000$ & $0.366 / 0.000$ & $0.247 / 0.000$ & \\
\hline
\end{tabular}

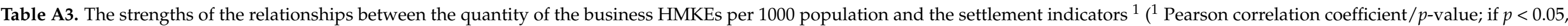

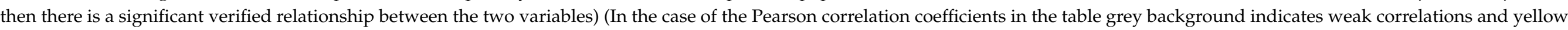

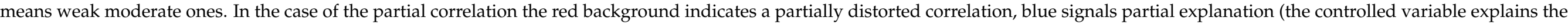
relationship between variables $i$ and $j$ only partially), while the black one shows irrelevant comparison.).

\begin{tabular}{|c|c|c|c|c|c|c|}
\hline \multirow[b]{2}{*}{ Indicator } & \multirow{2}{*}{$\begin{array}{c}\begin{array}{c}\text { Pearson Correlation } \\
\text { Coefficient }\end{array} \\
\begin{array}{c}\text { Business HMKEs per } \\
1000 \text { Population (pcs) }\end{array}\end{array}$} & \multicolumn{5}{|c|}{ Partial Correlation Coefficient } \\
\hline & & $\begin{array}{c}\text { Number of Registered } \\
\text { Businesses per } \\
1000 \text { Population (pcs) }\end{array}$ & $\begin{array}{c}\text { Total Budgetary } \\
\text { Revenue of the } \\
\text { Municipalities per } \\
1000 \text { Population (HUF } \\
\text { 1000) }\end{array}$ & $\begin{array}{c}\text { Total Budgetary } \\
\text { Expenditure of the } \\
\text { Municipalities per } \\
1000 \text { Population (HUF } \\
\text { 1000) }\end{array}$ & $\begin{array}{l}\text { Number of Electricity } \\
\text { Consumers per } \\
1000 \text { Population (pcs) }\end{array}$ & $\begin{array}{c}\text { Length of the } \\
\text { Low-Voltage Electricity } \\
\text { Distribution Network } \\
\text { per } 1000 \text { Population } \\
(\mathrm{km})\end{array}$ \\
\hline $\begin{array}{c}\text { Number of registered } \\
\text { businesses per } \\
1000 \text { population (pcs) }\end{array}$ & $0.305 / 0.000$ & & $0.250 / 0.000$ & $0.303 / 0.000$ & $0.145 / 0.000$ & $0.113 / 0.000$ \\
\hline
\end{tabular}


Table A3. Cont

\begin{tabular}{|c|c|c|c|c|c|c|}
\hline \multirow[b]{2}{*}{ Indicator } & \multirow{2}{*}{$\begin{array}{c}\begin{array}{c}\text { Pearson Correlation } \\
\text { Coefficient }\end{array} \\
\begin{array}{c}\text { Business HMKEs per } \\
1000 \text { Population (pcs) }\end{array}\end{array}$} & \multicolumn{5}{|c|}{ Partial Correlation Coefficient } \\
\hline & & $\begin{array}{c}\text { Number of Registered } \\
\text { Businesses per } \\
1000 \text { Population (pcs) }\end{array}$ & $\begin{array}{c}\text { Total Budgetary } \\
\text { Revenue of the } \\
\text { Municipalities per } \\
1000 \text { Population (HUF } \\
\text { 1000) }\end{array}$ & $\begin{array}{c}\text { Total Budgetary } \\
\text { Expenditure of the } \\
\text { Municipalities per } \\
1000 \text { Population (HUF } \\
\text { 1000) }\end{array}$ & $\begin{array}{l}\text { Number of Electricity } \\
\text { Consumers per } \\
1000 \text { Population (pcs) }\end{array}$ & $\begin{array}{c}\text { Length of the } \\
\text { Low-Voltage Electricity } \\
\text { Distribution Network } \\
\text { per } 1000 \text { Population } \\
(\mathrm{km})\end{array}$ \\
\hline $\begin{array}{c}\text { Total budgetary } \\
\text { revenue of the } \\
\text { municipalities per } \\
1000 \text { population (HUF } \\
\text { 1000) }\end{array}$ & $0.291 / 0.000$ & $0.266 / 0.000$ & & $0.205 / 0.000$ & $0.181 / 0.000$ & $0.151 / 0.000$ \\
\hline $\begin{array}{c}\text { Total budgetary } \\
\text { expenditure of the } \\
\text { municipalities per } \\
1000 \text { population (HUF } \\
\text { 1000) }\end{array}$ & $0.351 / 0.000$ & $0.246 / 0.000$ & $0.011 / 0.000$ & & $0.151 / 0.000$ & $0.131 / 0.000$ \\
\hline $\begin{array}{l}\text { Number of residential } \\
\text { electricity consumers } \\
\text { per } 1000 \text { population } \\
\text { (pcs) }\end{array}$ & $0.178 / 0.000$ & $0.271 / 0.000$ & $0.269 / 0.000$ & $0.327 / 0.000$ & $0.188 / 0.000$ & $0.106 / 0.000$ \\
\hline $\begin{array}{c}\text { Number of electricity } \\
\text { consumers per } \\
1000 \text { population (pcs) }\end{array}$ & $0.229 / 0.000$ & $0.251 / 0.000$ & $0.256 / 0.000$ & $0.310 / 0.000$ & & $0.050 / 0.000$ \\
\hline $\begin{array}{l}\text { Length of the } \\
\text { low-voltage electricity } \\
\text { distribution network } \\
\text { per } 1000 \text { population } \\
(\mathrm{km})\end{array}$ & $0.202 / 0.000$ & $0.258 / 0.000$ & $0.260 / 0.000$ & $0.319 / 0.000$ & $0.121 / 0.000$ & \\
\hline $\begin{array}{l}\text { Number of units of } \\
\text { operating commercial } \\
\text { accommodation units } \\
\text { per } 1000 \text { population } \\
\text { (pcs) }\end{array}$ & $0.144 / 0.000$ & $0.291 / 0.000$ & $0.271 / 0.000$ & $0.333 / 0.000$ & $0.193 / 0.000$ & $0.172 / 0.000$ \\
\hline $\begin{array}{l}\text { Number of businesses } \\
\text { in the hospitality } \\
\text { industry per } \\
1000 \text { population (pcs) }\end{array}$ & $0.047 / 0.020$ & $0.302 / 0.000$ & $0.288 / 0.000$ & $0.349 / 0.000$ & $0.234 / 0.000$ & $0.197 / 0.000$ \\
\hline
\end{tabular}




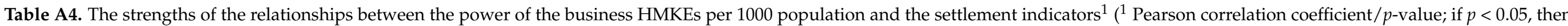

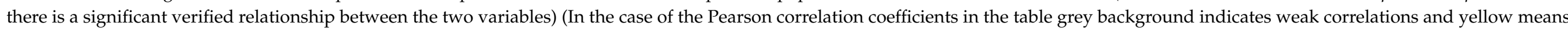

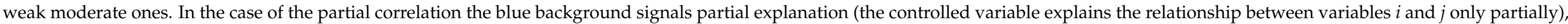
while the black one shows irrelevant comparison.).

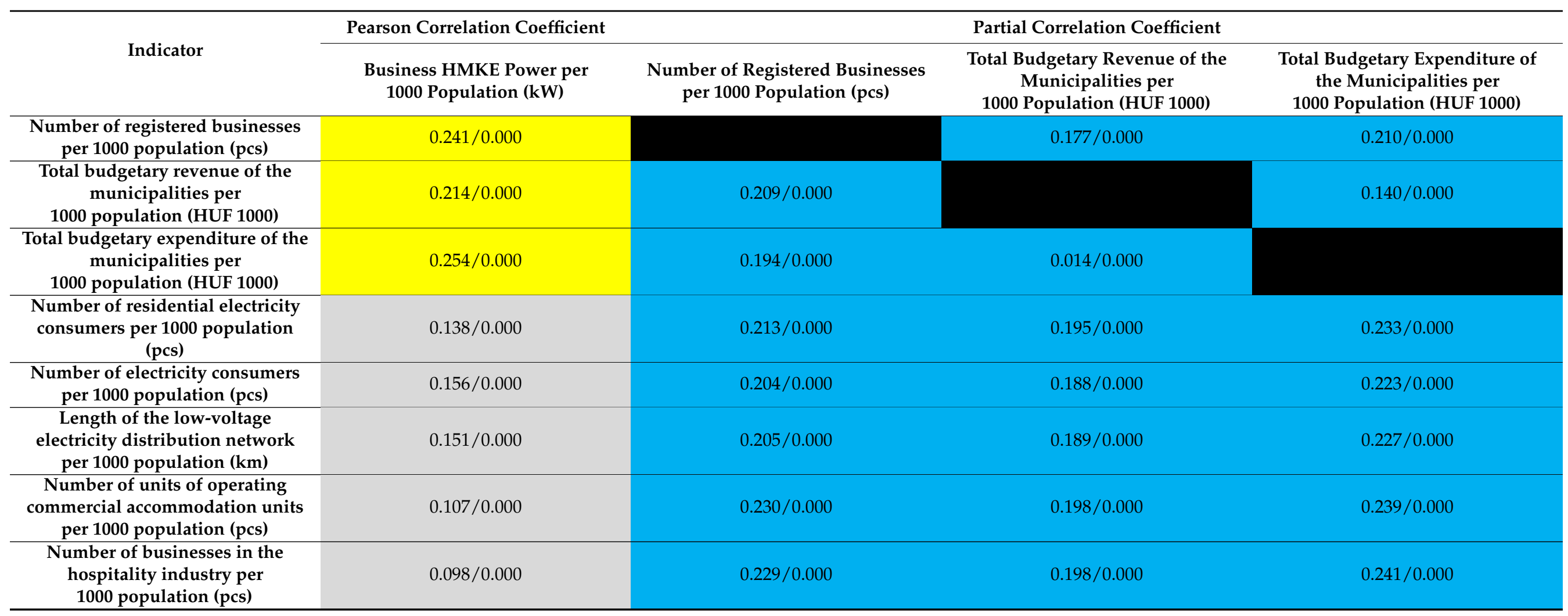




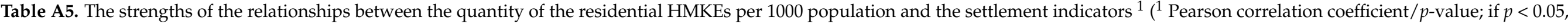

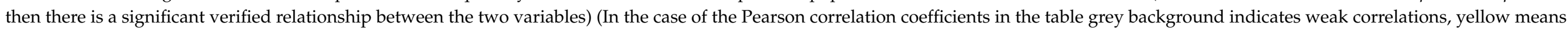

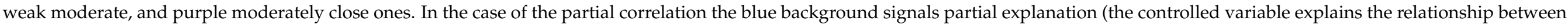
variables $i$ and $j$ only partially), while the black one shows irrelevant comparison.).

\begin{tabular}{|c|c|c|c|c|c|c|c|}
\hline \multirow[b]{2}{*}{ Indicator } & $\begin{array}{c}\text { Pearson } \\
\text { Correlation } \\
\text { Coefficient }\end{array}$ & \multicolumn{6}{|c|}{ Partial Correlation Coefficient } \\
\hline & $\begin{array}{c}\text { Residential } \\
\text { HMKEs per } \\
1000 \text { Population } \\
\text { (pcs) }\end{array}$ & $\begin{array}{c}\text { Number of } \\
\text { Residential } \\
\text { Electricity } \\
\text { Consumers per } \\
1000 \text { Population } \\
\text { (pcs) }\end{array}$ & $\begin{array}{c}\text { Number of } \\
\text { Electricity } \\
\text { Consumers per } \\
1000 \text { Population } \\
\text { (pcs) }\end{array}$ & $\begin{array}{c}\text { Number of } \\
\text { Registered } \\
\text { Businesses per } \\
1000 \text { Population } \\
\text { (pcs) }\end{array}$ & $\begin{array}{l}\text { Length of the } \\
\text { Low-Voltage } \\
\text { Electricity } \\
\text { Distribution } \\
\text { Network per } \\
1000 \text { Population } \\
(\mathrm{km})\end{array}$ & $\begin{array}{c}\text { Number of Units of } \\
\text { Operating } \\
\text { Commercial } \\
\text { Accommodation } \\
\text { Units per } \\
1000 \text { Population } \\
\text { (pcs) }\end{array}$ & $\begin{array}{c}\text { Number of } \\
\text { Businesses in the } \\
\text { Hospitality } \\
\text { Industry per } \\
1000 \text { Population } \\
\text { (pcs) }\end{array}$ \\
\hline $\begin{array}{c}\text { Number of registered } \\
\text { businesses per } \\
1000 \text { population (pcs) }\end{array}$ & $0.212 / 0.000$ & $0.479 / 0.000$ & $0.481 / 0.000$ & & $0.346 / 0.000$ & $0.174 / 0.000$ & $0.273 / 0.000$ \\
\hline $\begin{array}{l}\text { Total budgetary revenue of } \\
\text { the municipalities per } \\
1000 \text { population (HUF 1000) }\end{array}$ & $0.060 / 0.012$ & $0.503 / 0.000$ & $0.507 / 0.000$ & $0.205 / 0.000$ & $0.383 / 0.000$ & $0.196 / 0.000$ & $0.293 / 0.000$ \\
\hline $\begin{array}{l}\text { Total budgetary } \\
\text { expenditure of the } \\
\text { municipalities per } \\
1000 \text { population (HUF 1000) }\end{array}$ & $0.064 / 0.007$ & $0.502 / 0.000$ & $0.506 / 0.000$ & $0.204 / 0.000$ & $0.382 / 0.000$ & $0.195 / 0.000$ & $0.292 / 0.000$ \\
\hline $\begin{array}{l}\text { Number of residential } \\
\text { electricity consumers per } \\
1000 \text { population (pcs) }\end{array}$ & $0.505 / 0.000$ & & $0.074 / 0.000$ & $0.111 / 0.000$ & $0.029 / 0.000$ & $0.016 / 0.000$ & $0.051 / 0.000$ \\
\hline $\begin{array}{l}\text { Number of electricity } \\
\text { consumers per } \\
1000 \text { population (pcs) }\end{array}$ & $0.508 / 0.000$ & $-0.028 / 0.000$ & & $0.098 / 0.000$ & $0.014 / 0.000$ & $0.006 / 0.000$ & $0.044 / 0.000$ \\
\hline $\begin{array}{l}\text { Length of the low-voltage } \\
\text { electricity distribution } \\
\text { network per } \\
1000 \text { population }(\mathrm{km})\end{array}$ & $0.387 / 0.000$ & $0.353 / 0.000$ & $0.358 / 0.000$ & $0.106 / 0.000$ & & $0.121 / 0.000$ & $0.207 / 0.000$ \\
\hline $\begin{array}{l}\text { Number of units of } \\
\text { operating commercial } \\
\text { accommodation units per } \\
1000 \text { population (pcs) }\end{array}$ & $0.204 / 0.000$ & $0.472 / 0.000$ & $0.476 / 0.000$ & $0.184 / 0.000$ & $0.355 / 0.000$ & & $0.225 / 0.000$ \\
\hline
\end{tabular}




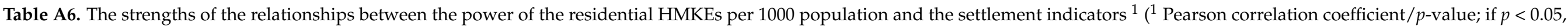

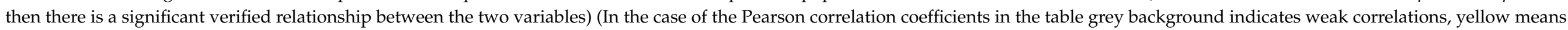

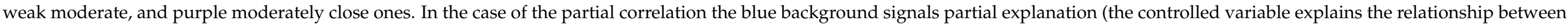
variables $i$ and $j$ only partially), while the black one shows irrelevant comparison.).

\begin{tabular}{|c|c|c|c|c|c|c|}
\hline \multirow[b]{2}{*}{ Indicator } & \multirow{2}{*}{$\begin{array}{c}\begin{array}{c}\text { Pearson Correlation } \\
\text { Coefficient }\end{array} \\
\begin{array}{c}\text { Residential HMKE } \\
\text { Power per }\end{array} \\
1000 \text { Population (kW) }\end{array}$} & \multicolumn{5}{|c|}{ Partial Correlation Coefficient } \\
\hline & & $\begin{array}{c}\text { Number of } \\
\text { Residential Electricity } \\
\text { Consumers per } \\
1000 \text { Population (pcs) }\end{array}$ & $\begin{array}{l}\text { Number of Electricity } \\
\text { Consumers per } \\
1000 \text { Population (pcs) }\end{array}$ & $\begin{array}{c}\text { Number of Registered } \\
\text { Businesses per } \\
1000 \text { Population (pcs) }\end{array}$ & $\begin{array}{c}\text { Length of the } \\
\text { Low-Voltage Electricity } \\
\text { Distribution Network } \\
\text { per } 1000 \text { Population } \\
(\mathbf{k m})\end{array}$ & $\begin{array}{c}\text { Number of } \\
\text { Businesses in the } \\
\text { Hospitality Industry } \\
\text { per 1000 Population } \\
\text { (pcs) }\end{array}$ \\
\hline $\begin{array}{c}\text { Number of registered } \\
\text { businesses per } \\
1000 \text { population (pcs) }\end{array}$ & $0.210 / 0.000$ & $0.381 / 0.000$ & $0.384 / 0.000$ & & $0.315 / 0.000$ & $0.205 / 0.000$ \\
\hline $\begin{array}{l}\text { Total budgetary revenue of } \\
\text { the municipalities per } \\
1000 \text { population (HUF 1000) }\end{array}$ & $0.054 / 0.024$ & $0.409 / 0.000$ & $0.415 / 0.000$ & $0.204 / 0.000$ & $0.354 / 0.000$ & $0.227 / 0.000$ \\
\hline $\begin{array}{l}\text { Total budgetary expenditure } \\
\text { of the municipalities per } \\
1000 \text { population (HUF 1000) }\end{array}$ & $0.059 / 0.014$ & $0.408 / 0.000$ & $0.414 / 0.000$ & $0.203 / 0.000$ & $0.354 / 0.000$ & $0.226 / 0.000$ \\
\hline $\begin{array}{l}\text { Number of residential } \\
\text { electricity consumers per } \\
1000 \text { population (pcs) }\end{array}$ & $0.411 / 0.000$ & & $0.099 / 0.000$ & $0.127 / 0.000$ & $0.091 / 0.000$ & $0.027 / 0.000$ \\
\hline $\begin{array}{l}\text { Length of the low-voltage } \\
\text { electricity distribution } \\
\text { network per } 1000 \text { population } \\
(\mathrm{km})\end{array}$ & $0.358 / 0.000$ & $0.235 / 0.000$ & $0.242 / 0.000$ & $0.112 / 0.000$ & & $0.141 / 0.000$ \\
\hline $\begin{array}{c}\text { Number of units of } \\
\text { operating commercial } \\
\text { accommodation units per } \\
1000 \text { population (pcs) }\end{array}$ & $0.155 / 0.000$ & $0.386 / 0.000$ & $0.392 / 0.000$ & $0.188 / 0.000$ & $0.334 / 0.000$ & $0.177 / 0.000$ \\
\hline $\begin{array}{l}\text { Number of businesses in the } \\
\text { hospitality industry per } \\
1000 \text { population (pcs) }\end{array}$ & $0.233 / 0.000$ & $0.349 / 0.000$ & $0.356 / 0.000$ & $0.178 / 0.000$ & $0.310 / 0.000$ & \\
\hline
\end{tabular}




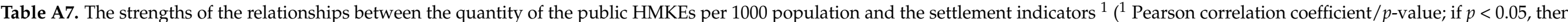

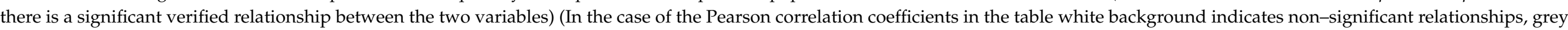

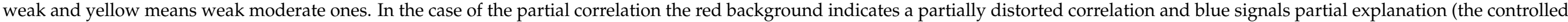
variable explains the relationship between variables $i$ and $j$ only partially), while black shows irrelevant comparison.)

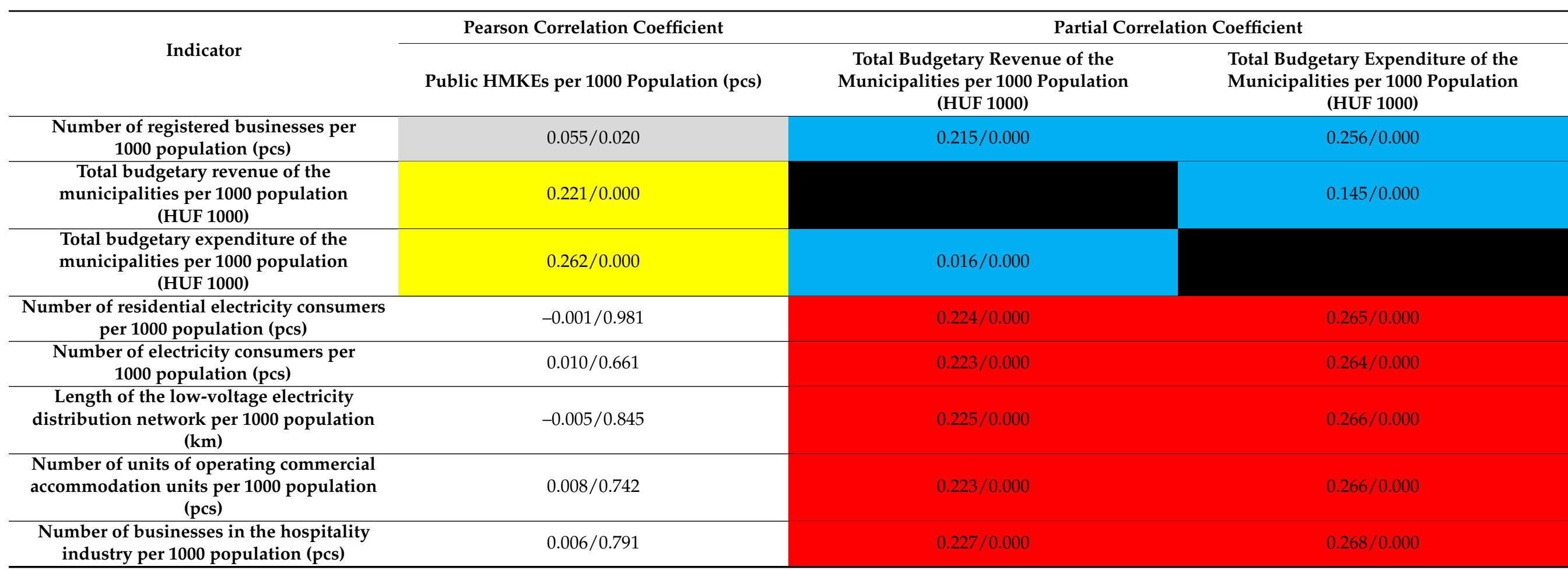




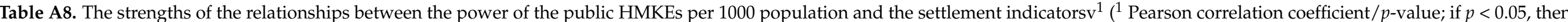

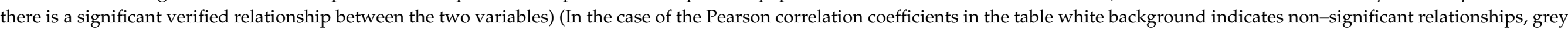

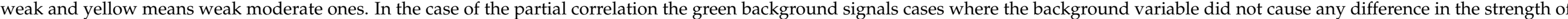

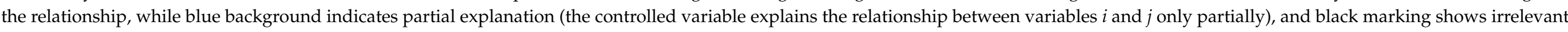
comparison.).

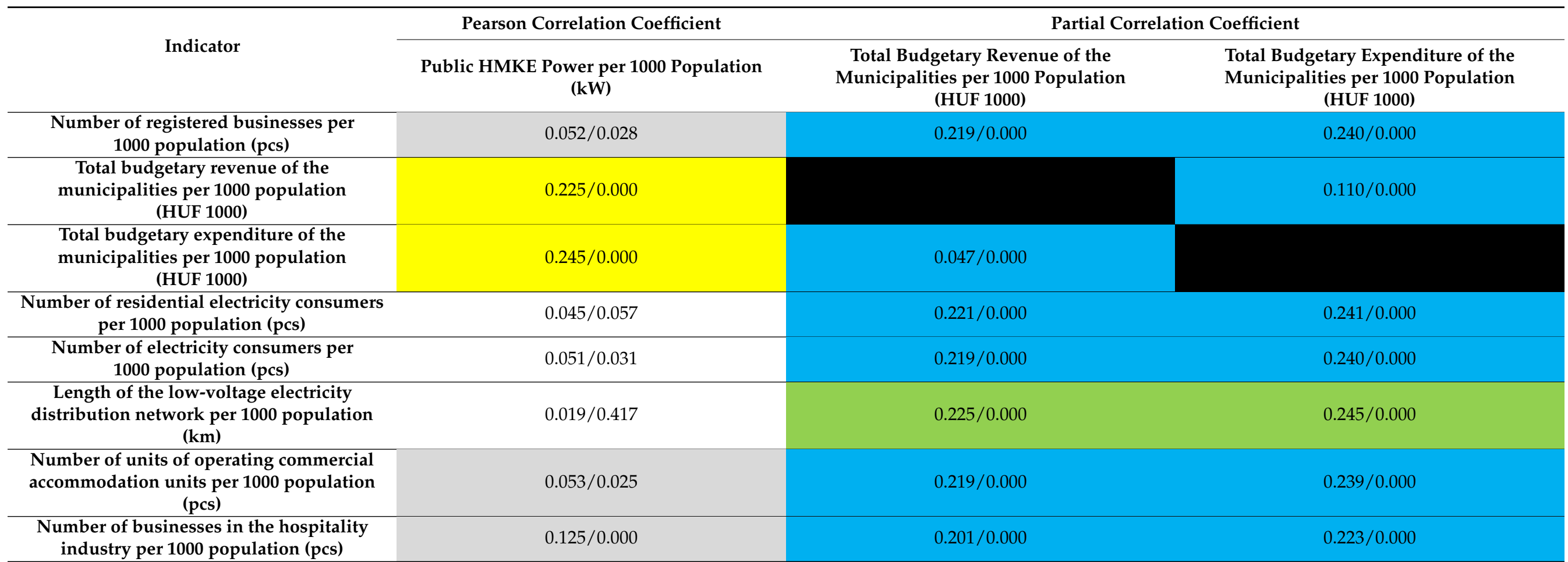




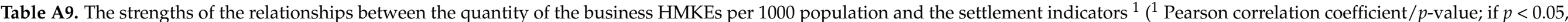

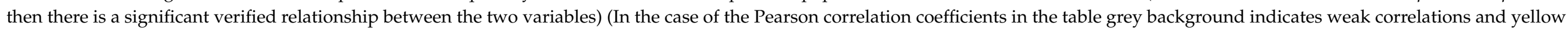

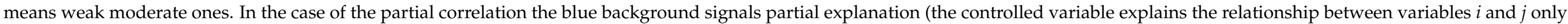
partially), while the black one shows irrelevant comparison.).

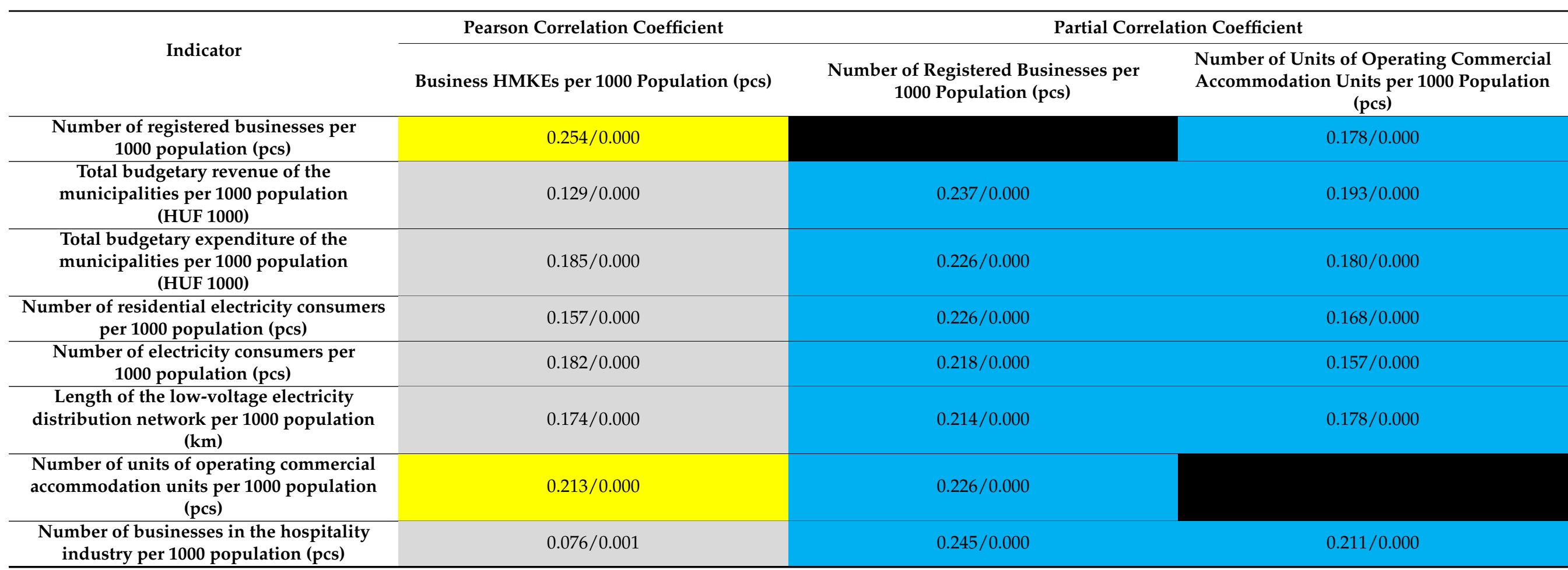


Table A10. The strengths of the relationships between the power of the business HMKEs per 1000 population and the settlement indicators ${ }^{1}\left({ }^{1}\right.$ Pearson correlation coefficient $/ p$-value; if $p<0.05$, then there is a significant verified relationship between the two variables) (In the case of the Pearson correlation coefficients in the table grey background indicates weak correlations.

\begin{tabular}{lc}
\hline \multicolumn{1}{c}{ Indicator } & $\begin{array}{c}\text { Business HMKE Power per } \\
\text { 1000 Population (kW) }\end{array}$ \\
\hline $\begin{array}{l}\text { Number of registered businesses per } \\
\text { 1000 population (pcs) }\end{array}$ & $0.130 / 0.000$ \\
\hline $\begin{array}{l}\text { Total budgetary revenue of the municipalities } \\
\text { per 1000 population (HUF 1000) }\end{array}$ & $0.113 / 0.000$ \\
\hline $\begin{array}{l}\text { Total budgetary expenditure of the } \\
\text { municipalities per 1000 population (HUF 1000) }\end{array}$ & $0.138 / 0.000$ \\
\hline $\begin{array}{l}\text { Number of residential electricity consumers per } \\
\text { 1000 population (pcs) }\end{array}$ & $0.063 / 0.008$ \\
\hline $\begin{array}{l}\text { Number of electricity consumers per } \\
\text { 1000 population (pcs) }\end{array}$ & $0.076 / 0.001$ \\
\hline $\begin{array}{l}\text { Length of the low-voltage electricity } \\
\text { distribution network per 1000 population (km) }\end{array}$ & $0.068 / 0.004$ \\
\hline $\begin{array}{l}\text { Number of units of operating commercial } \\
\text { accommodation units per 1000 population (pcs) }\end{array}$ & $0.082 / 0.001$ \\
\hline $\begin{array}{l}\text { Number of businesses in the hospitality } \\
\text { industry per 1000 population (pcs) }\end{array}$ & $0.055 / 0.022$ \\
\hline
\end{tabular}

\section{References}

1. International Renewable Energy Agency (IRENA). Global Energy Transformation: A Roadmap to 2050; IRENA: Abu Dhabi, UAE, 2018.

2. Renewable Energy Policy Network for the 21st Century (REN21). Renewables 2018 Global Status Report-REN21; REN21: Paris, France, 2018.

3. International Energy Agency (IEA). World Energy Outlook 2017; IEA: Paris, France, 2017.

4. Kim, K.J.; Lee, H.; Koo, Y. Research on local acceptance cost of renewable energy in South Korea: A case study of photovoltaic and wind power projects. Energy Policy 2020, 144, 111684. [CrossRef]

5. Dominković, D.F.; Bačeković, I.; Sveinbjörnsson, D.; Pedersen, A.S.; Krajačić, G. On the way towards smart energy supply in cities: The impact of interconnecting geographically distributed district heating grids on the energy system. Energy 2017, 137, 941-960. [CrossRef]

6. Kordmahaleh, A.A.; Naghashzadegan, M.; Javaherdeh, K.; Khoshgoftar, M. Design of a 25 MWe Solar Thermal Power Plant in Iran with Using Parabolic Trough Collectors and a Two-Tank Molten Salt Storage System. Int. J. Photoenergy 2017, 2017, 4210184. [CrossRef]

7. Noman, A.M.; Addoweesh, K.E.; Alolah, A.I. Simulation and Practical Implementation of ANFIS-Based MPPT Method for PV Applications Using Isolated Ćuk Converter. Int. J. Photoenergy 2017, 2017, 1-15. [CrossRef]

8. Daliento, S.; Chouder, A.; Guerriero, P.; Pavan, A.M.; Mellit, A.; Moeini, R.; Tricoli, P. Monitoring, Diagnosis, and Power Forecasting for Photovoltaic Fields: A Review. Int. J. Photoenergy 2017, 2017, 1-13. [CrossRef]

9. Sefa, İ.; Demirtas, M.; Çolak, İ. Application of one-axis sun tracking system. Energy Convers. Manag. 2009, 50, $2709-2718$. [CrossRef]

10. Nengroo, S.; Kamran, M.; Ali, M.; Kim, D.-H.; Kim, M.-S.; Hussain, A.; Kim, H.; Nengroo, S.H.; Kamran, M.A.; Ali, M.U.; et al. Dual Battery Storage System: An Optimized Strategy for the Utilization of Renewable Photovoltaic Energy in the United Kingdom. Electronics 2018, 7, 177. [CrossRef]

11. Turner, J.A. A realizable renewable energy future. Science 1999, 285, 687-689. [CrossRef] [PubMed]

12. Lin, A.; Lu, M.; Sun, P.; Lin, A.; Lu, M.; Sun, P. The Influence of Local Environmental, Economic and Social Variables on the Spatial Distribution of Photovoltaic Applications across China's Urban Areas. Energies 2018, 11, 1986. [CrossRef]

13. Liu, Z.; Wu, D.; Yu, H.; Ma, W.; Jin, G. Field measurement and numerical simulation of combined solar heating operation modes for domestic buildings based on the Qinghai-Tibetan plateau case. Energy Build. 2018, 167, 312-321. [CrossRef]

14. Alsafasfeh, M.; Abdel-Qader, I.; Bazuin, B.; Alsafasfeh, Q.; Su, W.; Alsafasfeh, M.; Abdel-Qader, I.; Bazuin, B.; Alsafasfeh, Q.; $\mathrm{Su}, \mathrm{W}$. Unsupervised Fault Detection and Analysis for Large Photovoltaic Systems Using Drones and Machine Vision. Energies 2018, 11, 2252. [CrossRef]

15. Hosenuzzaman, M.; Rahim, N.A.; Selvaraj, J.; Hasanuzzaman, M.; Malek, A.B.M.A.; Nahar, A. Global prospects, progress, policies, and environmental impact of solar photovoltaic power generation. Renew. Sustain. Energy Rev. 2015, 41, 284-297. [CrossRef] 
16. Roth, W. General Concepts of Photovoltaic Power Supply Systems; Fraunhofer Institute for Solar Energy Systems ISE: Freiburg, Germany, 2005; pp. 1-23.

17. Kumar Sahu, B. A study on global solar PV energy developments and policies with special focus on the top ten solar PV power producing countries. Renew. Sustain. Energy Rev. 2015, 43, 621-634. [CrossRef]

18. Renewable Energy Policy Network for the 21st Century. Renewables 2020 Global Status Report-REN21; REN21: Paris, France, 2020.

19. Solargis.com. Solar Resource Maps and GIS Data for 200+ Countries. Available online: https://solargis.com/maps-and-gisdata/overview (accessed on 28 October 2020).

20. PV Magazine. Hungary to See Record PV Growth in 2018. Available online: https://www.pv-magazine.com/2018/09/12 / hungary-to-see-record-pv-growth-in-2018/ (accessed on 28 October 2020).

21. Hungarian Transmission System Operator-MAVIR ZRt. Renewable Support System—Current Information. Available online: https: / /www.mavir.hu/web / mavir/aktualis-informaciok (accessed on 28 October 2020).

22. Fülöp, M. Múködik az első Hazai Közcélú Energiatároló Egység—The First Domestic Public Energy Storage Unit Is Operating. Available online: https:/ / www.villanylap.hu/hirek/4904-mukodik-az-elso-hazai-kozcelu-energiatarolo-egyseg (accessed on 28 October 2020).

23. Igazságügyi Minisztérium. Magyar Közlöny, 2019. évi 222. Szám; Igazságügyi Minisztérium: Budapest, Hungary, 2019.

24. Magyar Villamosenergia-Ipari Átviteli Rendszerirányító Zártkörúen Múködő Részvénytársaság (MAVIR ZRt.). A Magyar VER Fogyasztói és Forrásoldali Jövőképe 2020-2040-Input Adatok; MAVIR ZRt.: Budapest, Hungary, 2020.

25. Fraunhofer Institute for Solar Energy Systems. Photovoltaics Report; Fraunhofer Institute for Solar Energy Systems: Freiburg, Germany, 2018.

26. Hungarian Energy and Public Utility Regulatory Authority. Renewable Energy Operating Aid. Available online: https://www. enhat.mekh.hu/mukodesi-tamogatas (accessed on 25 August 2020).

27. Hungarian Energy and Public Utility Regulatory Authority. Report—On Quarterly New Household-Sized Power Plants (Q4 2019); Hungarian Energy and Public Utility Regulatory Authority: Budapest, Hungary, 2019.

28. Wolters Kluwer Hungary Kft. 84/1993. (XI. 11.) OGY Decision. Available online: https://mkogy.jogtar.hu/jogszabaly?docid=99 3h0084.OGY (accessed on 17 September 2020).

29. Wolters Kluwer Hungary Kft. 290/2014. (XI. 26.) Government Decree. Available online: https://net.jogtar.hu/jogszabaly?docid= a1400290.kor (accessed on 17 September 2020).

30. Wolters Kluwer Hungary Kft. 105/2015. (IV. 23.) Government Decree. Available online: https://net.jogtar.hu/jogszabaly?docid= a1500105.kor (accessed on 17 September 2020).

31. Kovács, P.; Bodnár, G. Examining the Factors of Endogenous Development in Hungarian Rural Areas by Means of PLS Path Analysis. Reg. Stat. 2017, 7, 90-114. [CrossRef]

32. Valkó, G.; Fekete-Farkas, M.; Kovács, I. Indicators for the economic dimension of sustainable agriculture in the European Union. Reg. Stat. 2017, 7, 179-196. [CrossRef]

33. Hungarian Central Statistical Office (KSH). Information Database, Regional Statistics. Available online: http://statinfo.ksh.hu/ Statinfo/themeSelector.jsp?lang=hu (accessed on 17 September 2020).

34. Land Information System (TEIR). Application Supporting the Planning of LEADER Local Development Strategies. Available online: https: / /www.teir.hu/leader/ (accessed on 17 September 2020).

35. Foster, G.C.; Lane, D.; Scott, D.; Hebl, M.; Guerra, R. An Introduction to Psychological Statistics; University of Missouri-St. Louis: St. Louis, MO, USA, 2018.

36. Illowsky, B.; Dean, S. Introductory Statistics; 12th Media Services: Suwanee, GA, USA, 2017.

37. Freedman, D.; Pisani, R.; Purves, R. Statistics, 4th ed.; W. W. Norton \& Company: New York, NY, USA, 2017.

38. Zaid, M.A. Correlation and Regression Analysis; The Statistical, Economic and Social Research and Training Centre for Islamic Countries (SESRIC): Ankara, Turkey, 2015.

39. Montgomery, C.D.; Peck, A.E.; Vining, G.G. Introduction to Linear Regression Analysis, 5th ed.; Wiley: Hoboken, NJ, USA, 2012.

40. Pintér, G.; Zsiborács, H.; Hegedû́sné Baranyai, N.; Vincze, A.; Birkner, Z. The Economic and Geographical Aspects of the Status of Small-Scale Photovoltaic Systems in Hungary-A Case Study. Energies 2020, 13, 3489. [CrossRef]

41. Lechner Nonprofit Kft. Map of Utilities. Available online: https:/ /www.e-epites.hu/e-kozmu (accessed on 17 September 2020). 